\title{
PEACE ADVOCACY AND THE BASIS OF BUILDING FOREIGN RELATIONS OF ISLAMIC STATES IN THE QURAN
}

\section{السلّهُ اللدعوي وأُسس بناء العلاقات الخارجية للدولة الإسلامية في القرآن}

\section{Mahmoodalnor Hamoda}

Eldaen University, Sudan

E-mail: ez13666@gmail.com

\section{Abstract}

This study addressed the knowledge of the peace advocacy and building foreign relations of Islamic states in the Holy Quran. Whoever reads the book of Allah almighty may find it full of the vocabulary of peace advocacy, and relations between nations and people. The study included examples mentioned in the Holy Quran showing the need for peace and the foundations of building relations between nations and people. It addressed the meanings of peace advocacy and its importance. It also showed that the peace advocacy and Islam call of prophets and messengers (peace be on them) and the way of the righteous and reformers. The origin in the relationship of Muslims to others is peace and the call to God, not war, and not fighting. Islam is a religion of mercy and happiness for humanity, and it is not spread by the sword, but by proof, argument, wisdom and good preaching. With this peace advocacy and peace that the Quran has guided us to, love and communication will replace hatred and result in intimacy between Muslim and non-Muslim communities. The results of the study showed that the importance of preachers need in this era and save life from 
evil and sedition. Thus, the society is safe from conflicts, peaceful and reformed.

اشتملت هذه الدراسة على معرفة السِّلْمُ الدعوي ويناء العلاقات الخارجية

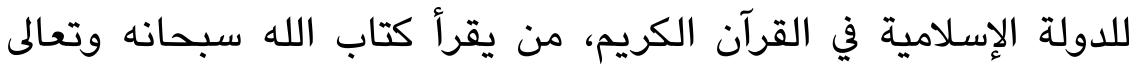

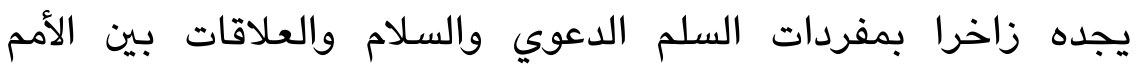
والشعوب. ضم البحث نماذج ذكرها القرآن الكريم، توضح لنا وللأمة

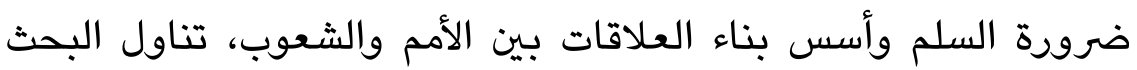

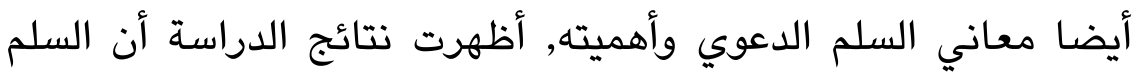

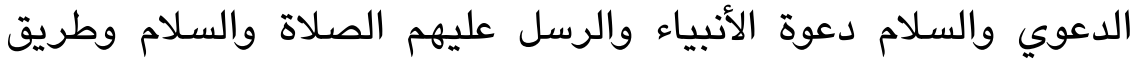
الصالحين والمصلحين، والأصل في علاقة المسلمين بغيرهم هو السلم السياء والدعوة إلى الله وليس الحرب ولا القتال، الإسلام دين الرحمة والسعادة

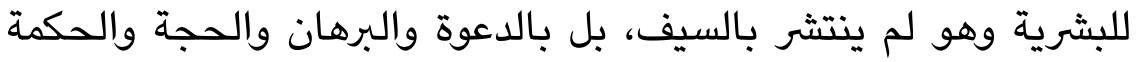

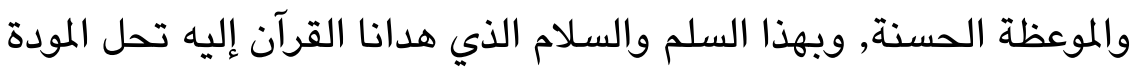

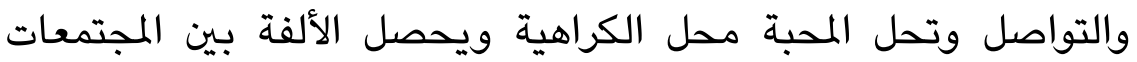
المسلمة وغير المسلمة، وذكرت نتائج الدراسة المهمة التي يحتاجها الدعاة

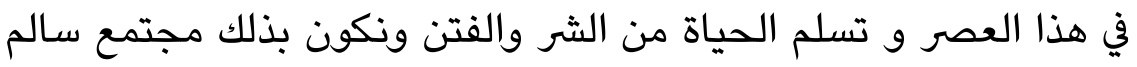

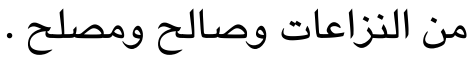

Keywords: foreign relations; Islamic state; peace advocacy; Quran

Received: February 6, 2020; Accepted: May 5, 2020

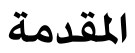

الحمد لله رب العالمين والصلاة والسلام على سيد الدعاة ومعلم الناس

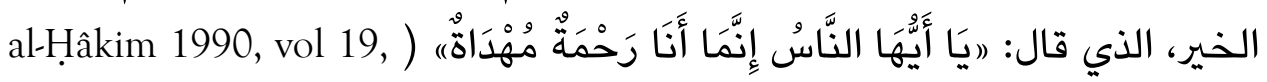
no. hadith 100, 91 والدعوة، فقد أنزل الله الإسلام دينا للناس أجمعين، وجعل تبليفه والدعوة إليه من إليه 


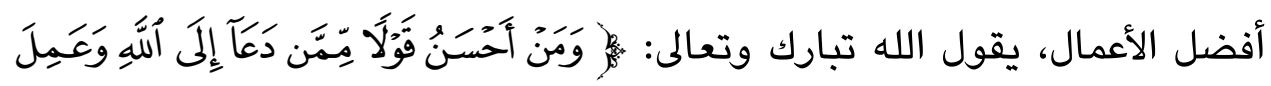

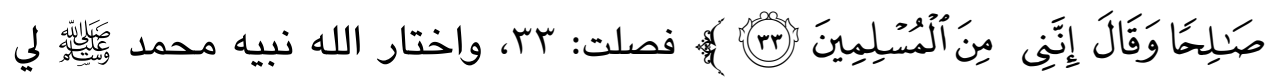

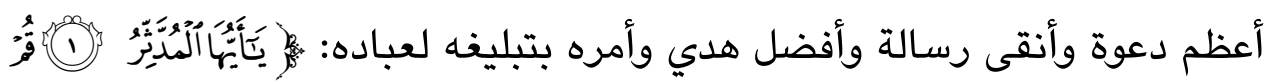

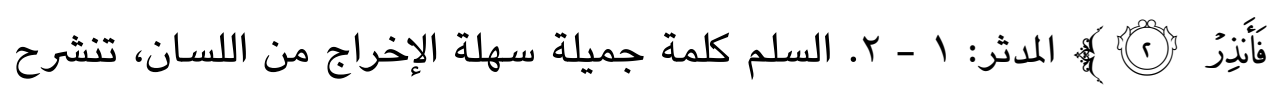

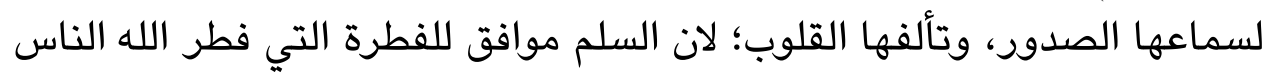
عليها.

\section{تعريف السَّلْمِ}

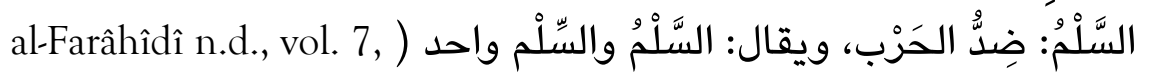

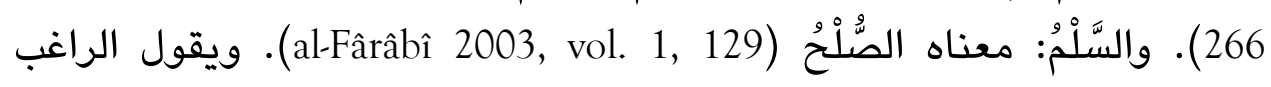

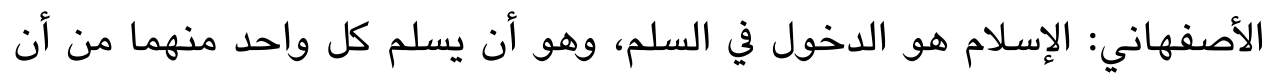

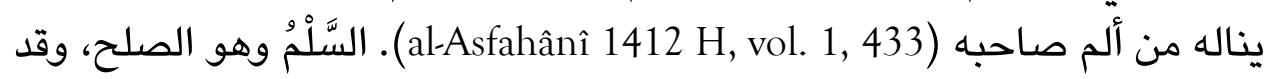

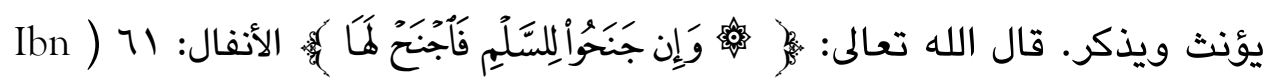
Fâris 1979, vol. 3, 91

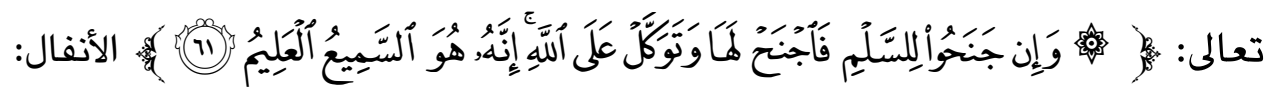

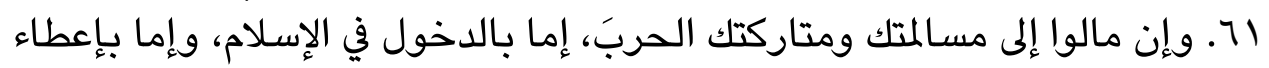

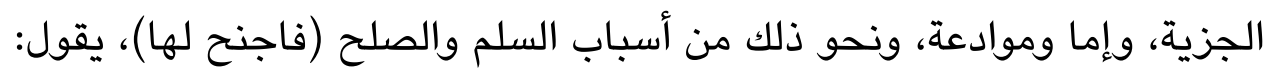
فمل إليها، وابذل لهم ما مالوا إليه من ذلك وسألك ونس ألوه (al-Ṭabarî 2000, vol. 14, 40).

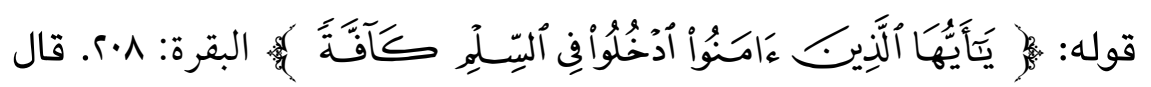

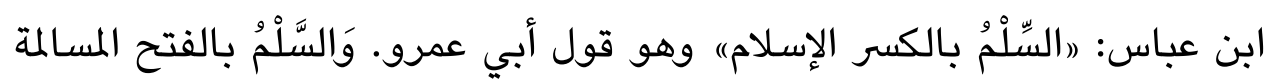

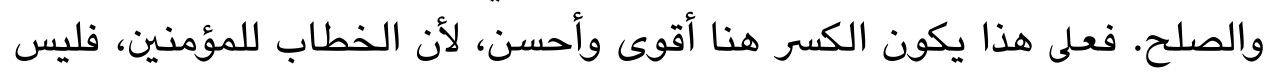

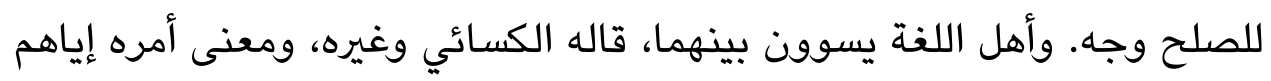

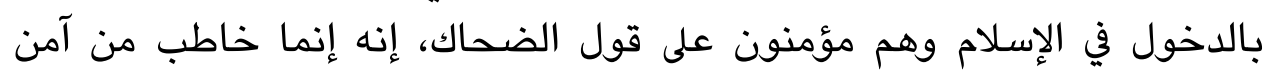

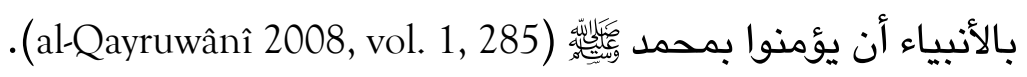


تعريف الإسلام: مصدره من أسلم يسلم، ومنه السلامة والسلام. الإسلام هو دين الله الذي أنزله على جميع الأنبياء، فقد دعوا جميعاً إلى أصول واحدة، تقدوم

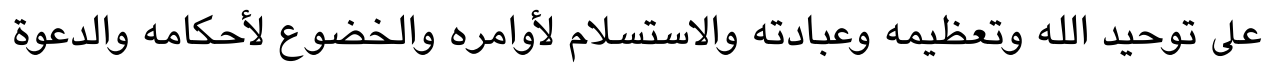
إلى حراسة فضائل الأخلاق والارتقاء بالسلوك الإنساني. قال ابن قتيبة: الإسلام

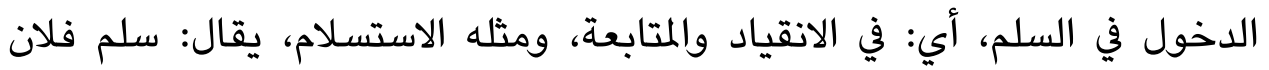
لأمرك، واستسلم، وأسلم (Ibn al-Jawzî 1422 H, vol. 1, 267).

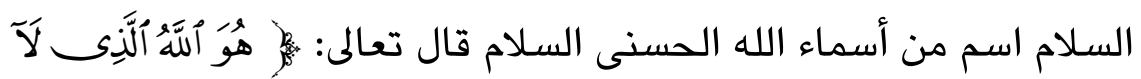

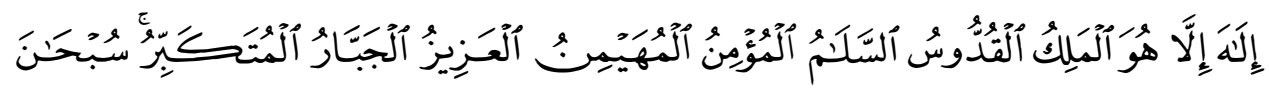

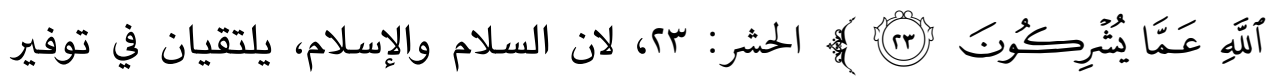
الطمأنينة، والأمن، والسكينة للناس إن الإسلام يوجب العدل ويحرم الظلم، ويجعل من تعاليمه السامية وقيمه الرفيعة من المودة، والرحمة، والتعاون، والإيثار،

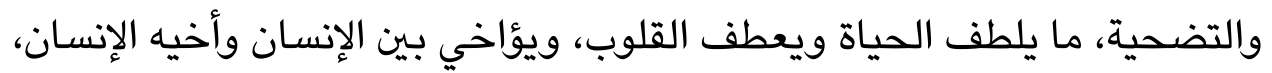

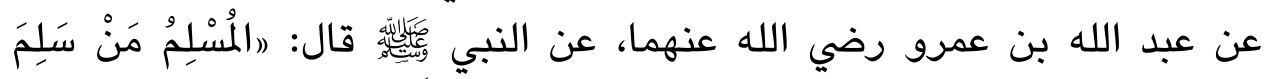

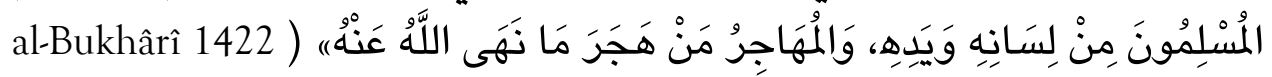
.(H, vol. 1 , no. hadith 10,11

\section{تعريف الدعوة}

الدعوة لغة: الدعوَة الى الطعام بالفتح. يقال: كنا في دعوَة فلان ومدعاة

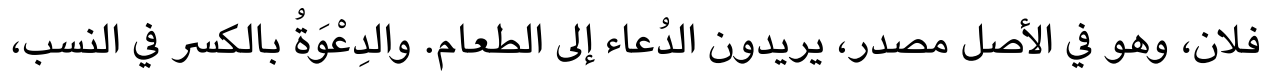

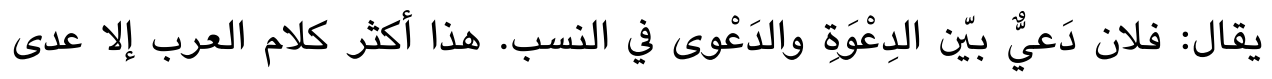

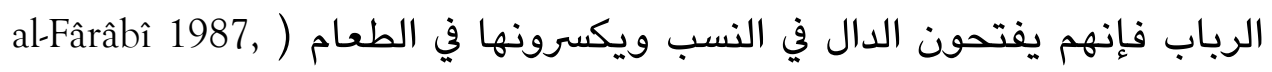

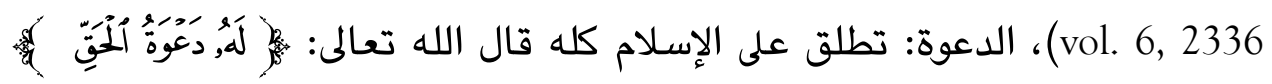
الرعد: عا، فيقال دعوة الإيمان، ودعوة الإسلام، ودعوة الأنبياء، والمؤذن يدعوا 
الناس إلى الصلاة. دعو: (يقال) دعوتُ أدعو دعاء: والدعوة: المرَّةُُّ الواحدة، والدعوة

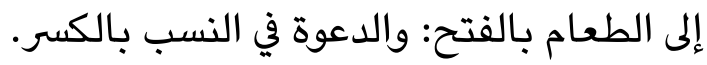
قال أبو عبيدة: (يقال في النسب دعوة بالكسر، وإلى الطعام دعوة)، وهذا

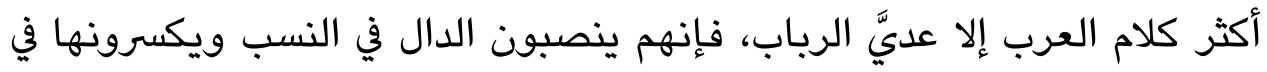

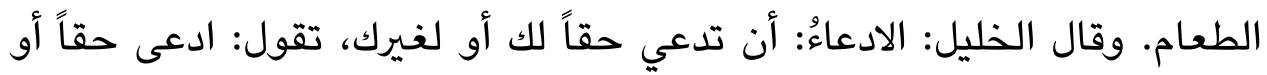
باطلاً (Ibn Fâris 1986, vol. 6, 326).

الدعوة اصطلاحا: ورد لها عدة تعريفات يكمل بعضها بعضا، منها:

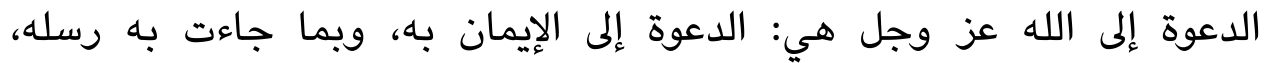

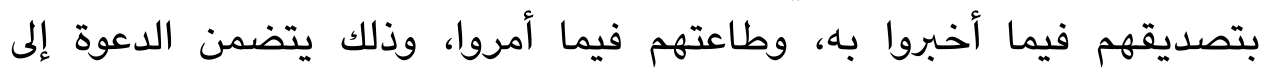

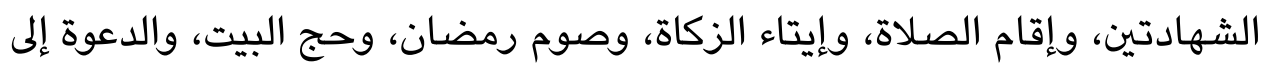

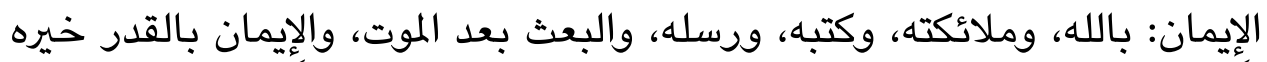

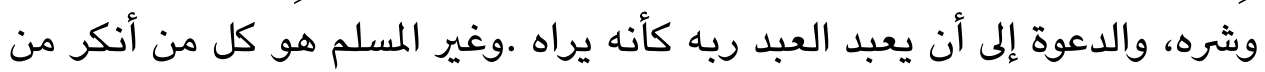

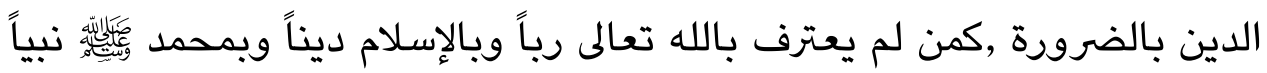
ورسولاً (Ibn Taymiyah 1995, vol. 15, 157).

\section{حكم الدعوة إلى الله}

دلت نصوص الكتاب والسنة على وجوب الدعوة إلى الله، فآيات القرآن

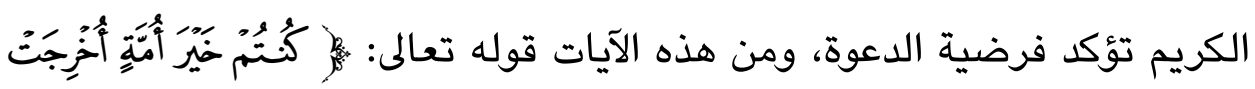

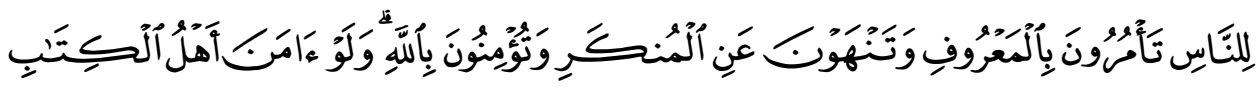

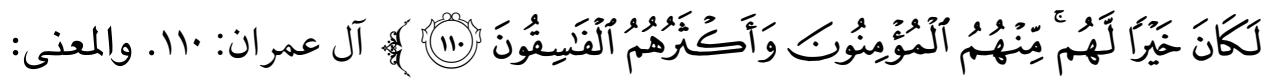

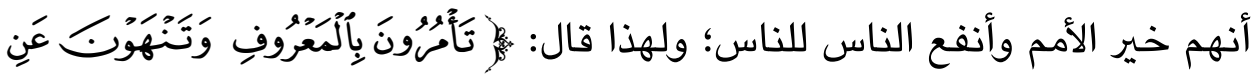

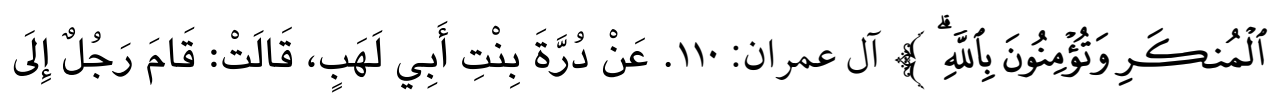

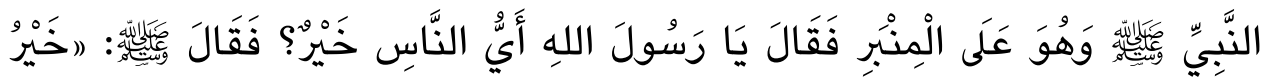




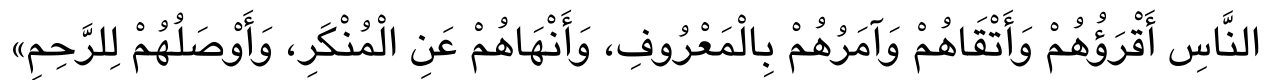
.(Aḥmad 2001, vol. 45, no. hadith 27434, 421; Ibn Kathîr 1999, vol. 2, 93 )

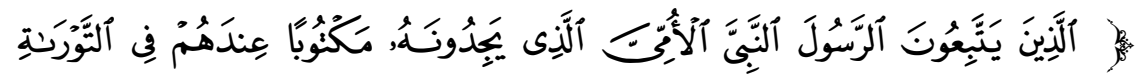

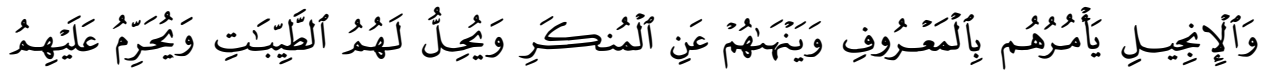

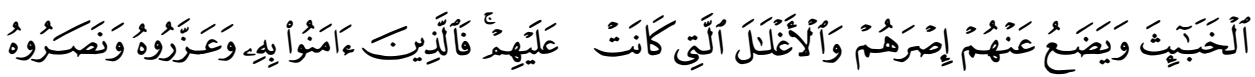

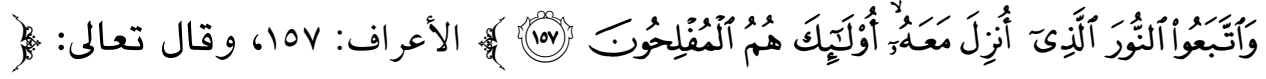

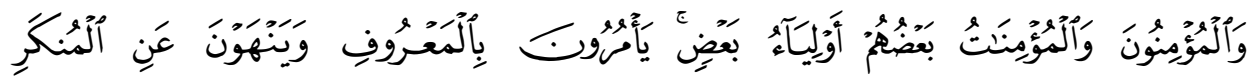

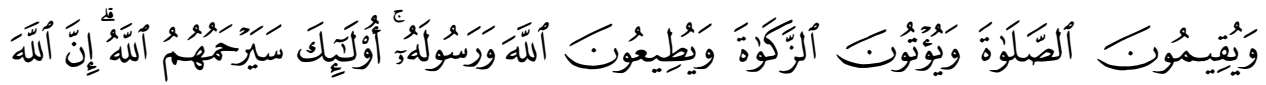

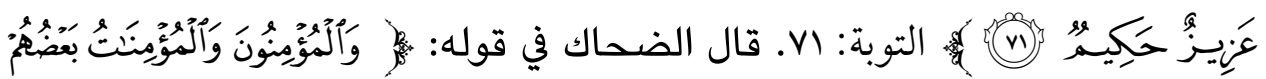

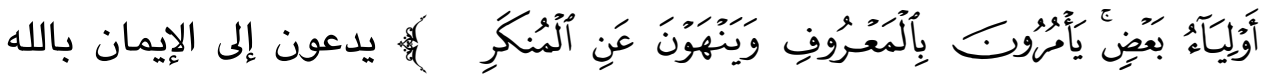

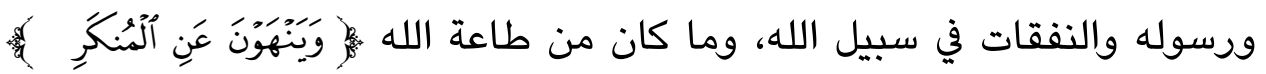

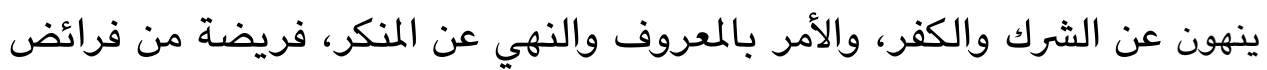
الله كتبها الله على المؤمنين (al-Suyûtî n.d., vol. 4, 234).

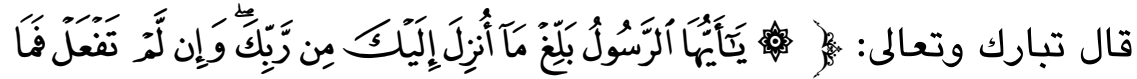

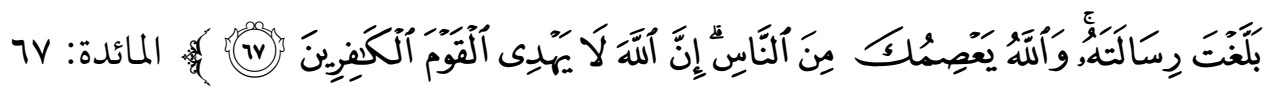

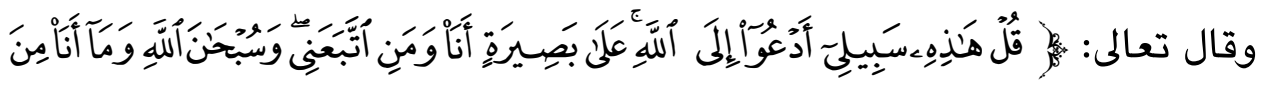

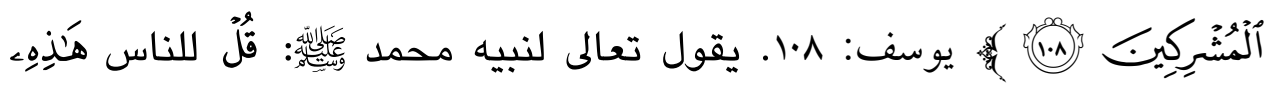
سِبِيلِي أي: طريقي التي أدعو إليها، وهي السبيل الموصلة إلى الله وإلى دار كرامته،

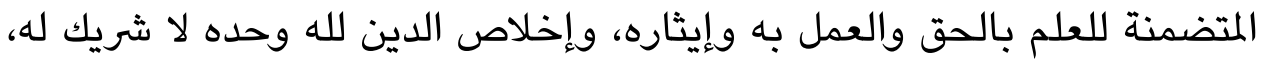

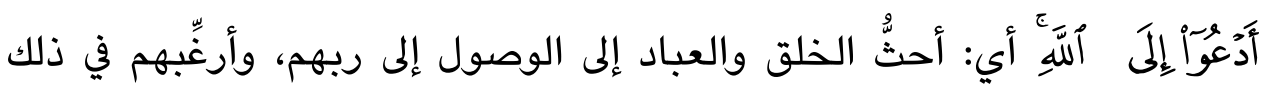

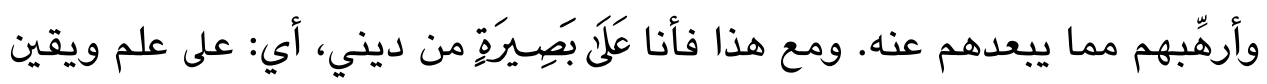
Ulul Albab Volume 21, No.1 Tahun 2020 
من غير شك ولا امتراء ولا مرية. وكذلك وَمَنِ أَتَبَعَنِى يدعو إلى الله كما أدعو على بصيرة من أمره. وَسُبحََنَ الَلَّهِ عما نسب إليه مما لا يليق بجلاله، أو ينافي كماله. وَمَآ

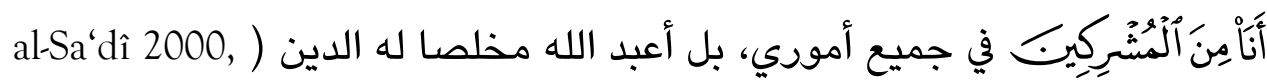
.(vol. 1, 406

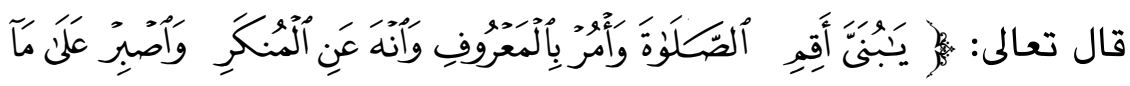

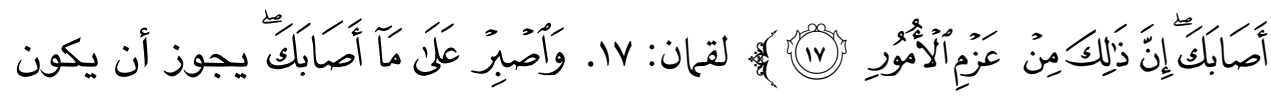

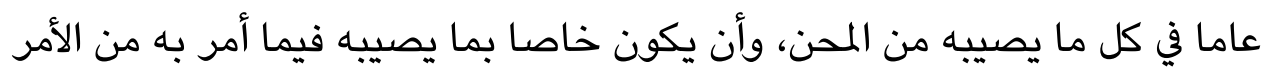

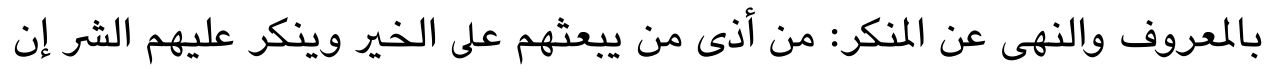

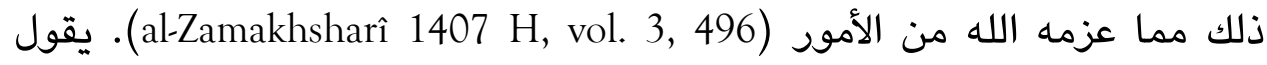

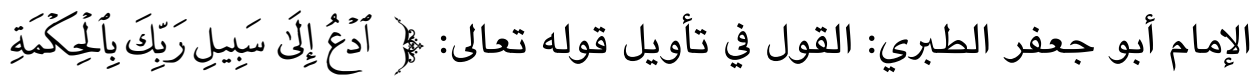

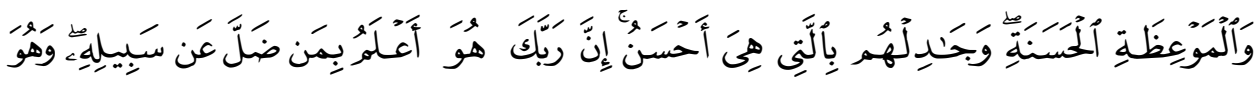

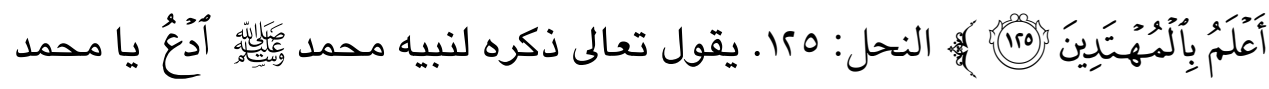
من أرسلك إليه ريك بالدعاء إلى طاعته إِلَّى سَبِيلِ رَبِكَكَ يقول: إلى شريعة ريك التي ثَرعها لخلقه، وهو الإسلام بِاَلِِْكَمَة يقول بوحي الله الذي يوحيه إليك وكتابه

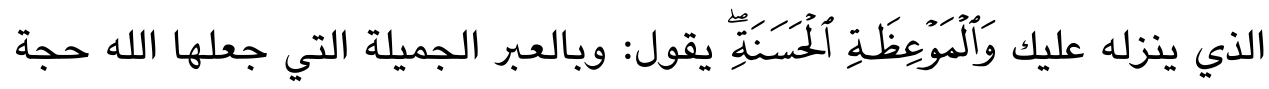

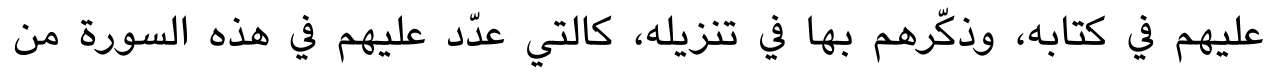

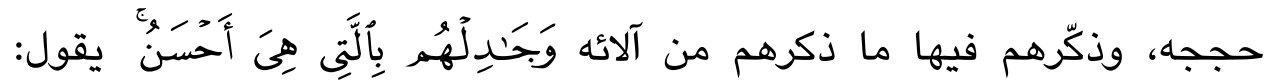

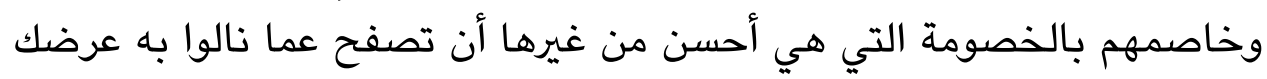

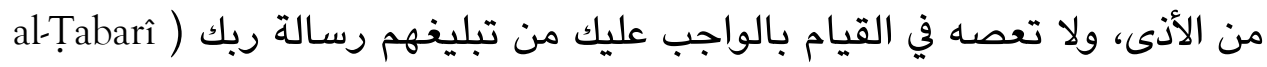
.(2000, vol. 17, 321 


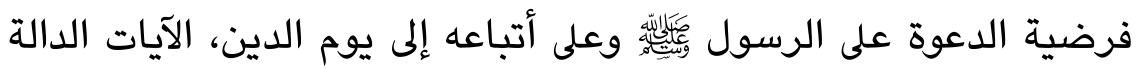

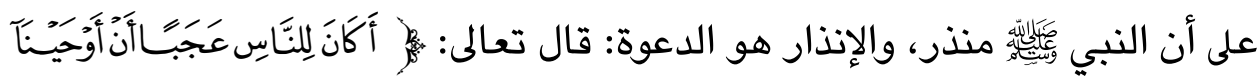

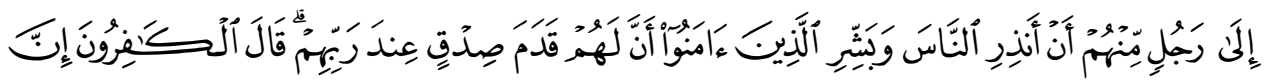

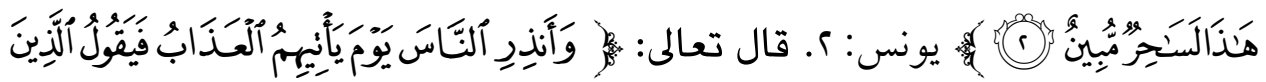

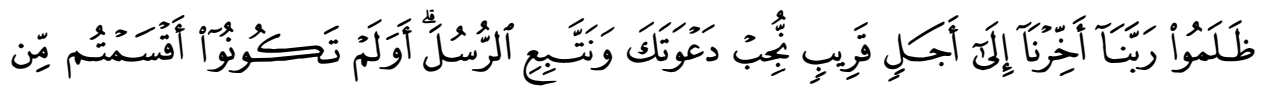

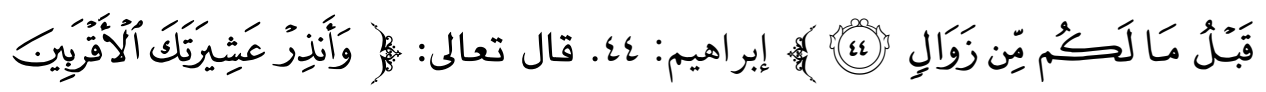

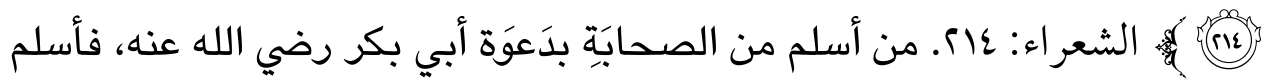

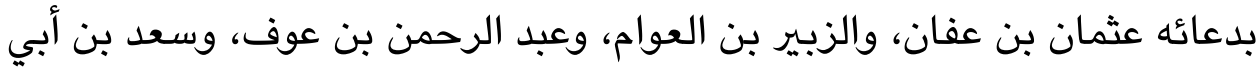

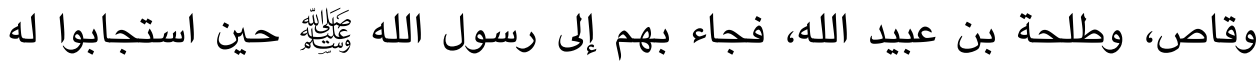

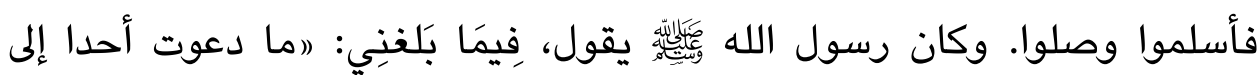

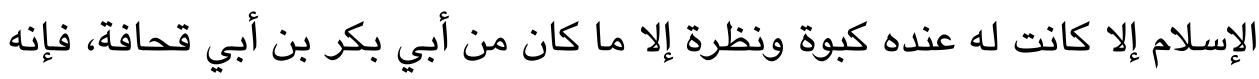
ما عكم حين ذكرته له ولا تردد فيه، (Ibn Hishâm n.d., vol. 1, 232).

\section{الأسس التي بنيت عليها العلاقات الخارجية للدولة الإسلامية}

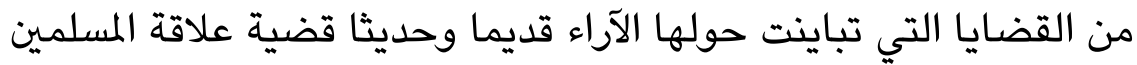

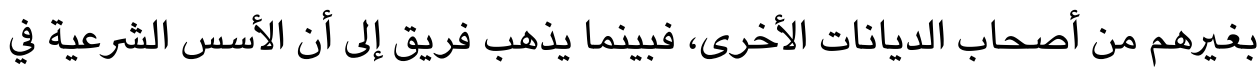

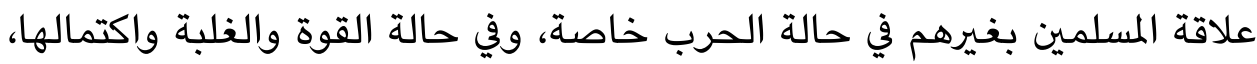

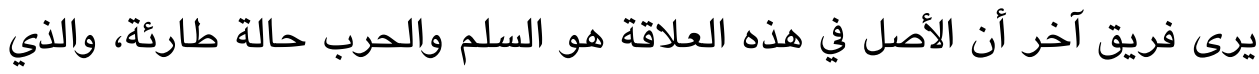
نميل إليه أن السلم الدعوي هو الأصل في العلاقة بين المسلمين وغيرهم هو السلم

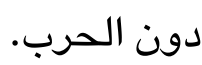

فأمة الإسلام أمة رسالة، تعتقد أن الله سبحانه وتعالى ابتعتها لإيصال الخير والتوحيد إلى الأمم الأخرى، فالعلاقة بين المسلمين وغيرهم تنبني في أساسها لإنها 
ومصدرها على الدعوة ومقتضى ذلك أن العلاقات بين المسلمين وغيرهم تنشأ وفقا

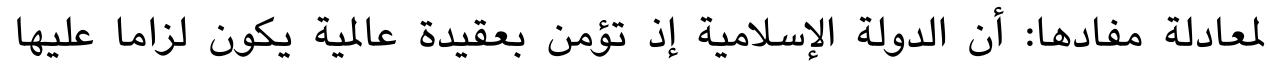

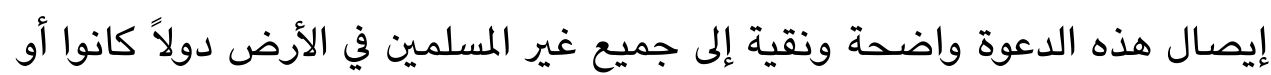

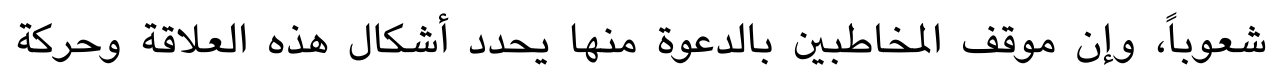
تطورها. واعتبارُ الدعوة مناطا للعلاقات الخارجية للدولة الإسلامية، يجد له سنداً قوياً وثابتاً في كافة المصادر الأصولية للشريعة الإسلامية.

التعايش السلمي في القرآن الكريم أسس بناء العلاقات الخارجية للدولة الإسلامية

الإسلام أسس علاقة المسلمين بغيرهم على المسالمة والأمان وقبول الآخر ولا

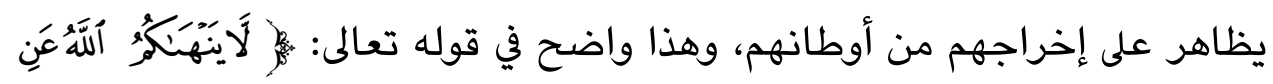

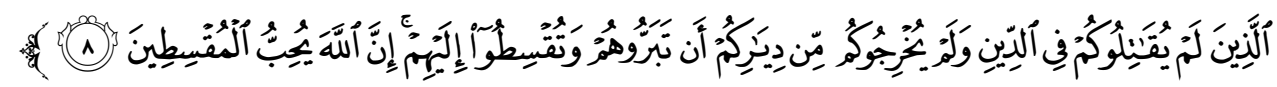

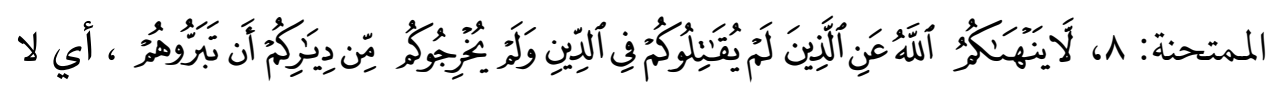

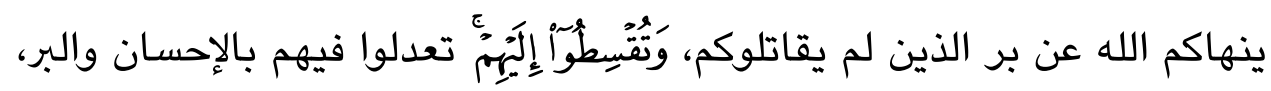

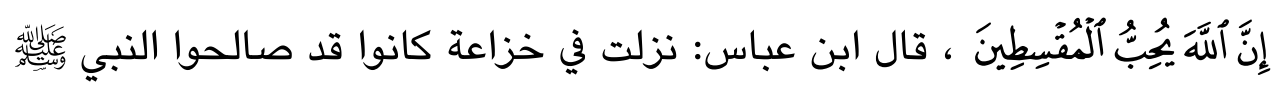

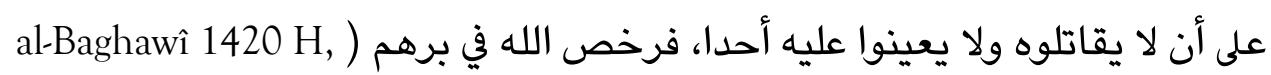

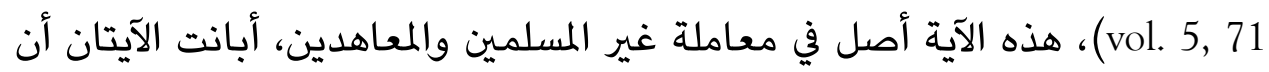
للكفار من المسلمين موقفين: إما المسالمة وإما المعاداة. وحددت علاده علاقة المسلمين بغيرهم في تلك الحالتين. فيجوز برهم وفعل الخير لهم، والحكم بينهم وبين غيرهم بالعدل إذا لم يقاتلوا في الدين أو الدنيا، ولم يخرجوا المؤمنين من ديارهم، ولم يعينوا على

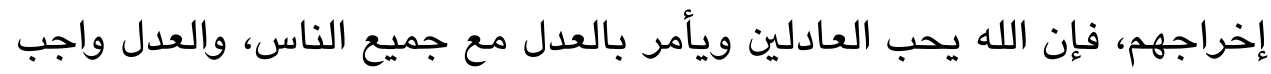

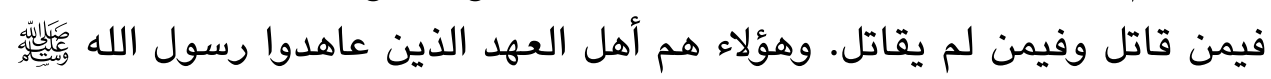

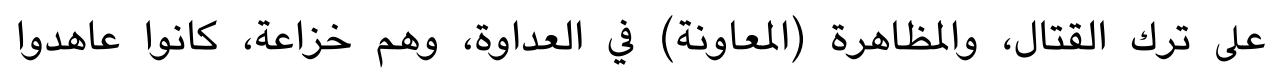




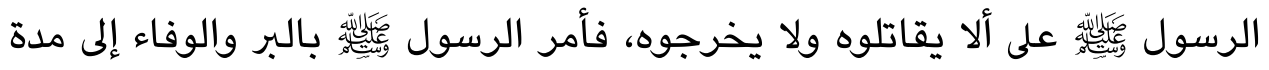

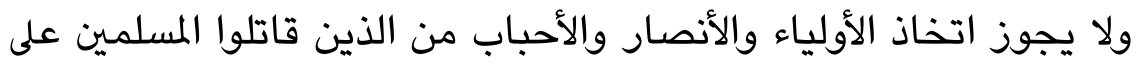

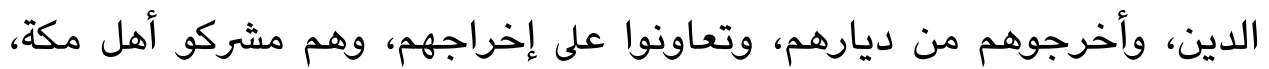

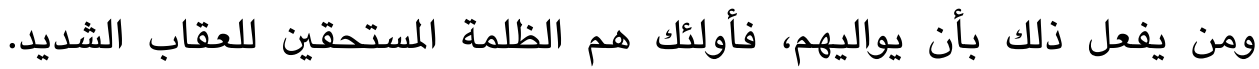
والخلاصة: لا ينهى الله عن مباراة الفريق الأول، وإنما ينهى عن تولي الفريق يون

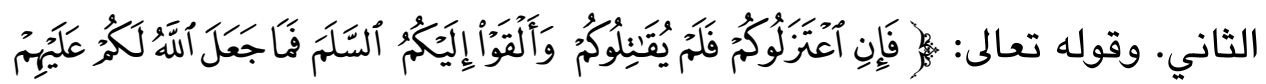

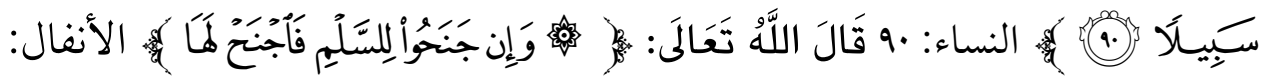
ا7 وفي كثير من آيات القرآن الكريم وأصول الدين ما يعزز هذه الروح السلمية ويبعد أن يكون الإسلام أسس علاقات المسلمين بغيرهم على الحرب الدائمة وأن

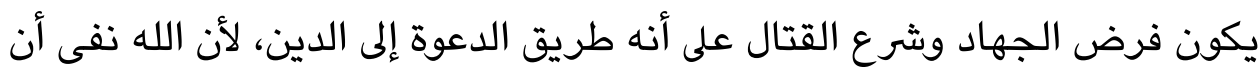

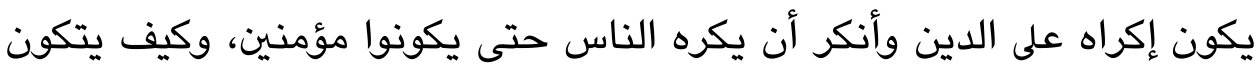
الإيمان بالإكراه ويصل السيف إلى القلوب إن طريق الدعوة إنى إلى الى التوحيد والإخلاص لله وحده هي الحجة لا السيف ولو أن غير المسلمين كفوا عن فتنتهم وتركهم

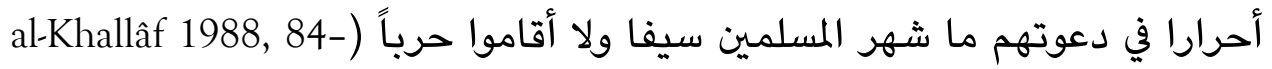

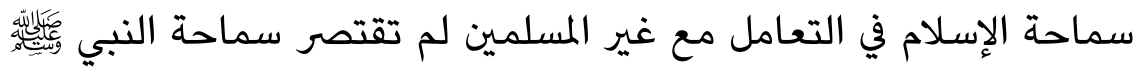
مع المسلمين فقط بل شملت أهل الكتاب والمشركين أثناء الحرب فقد أوصى بالقبط خيرًا وثبت عنه أنه قال: إذا افتتحتم مصر فاستوصوا بالقبط اهليط خيرا، فإن لهم ذمة

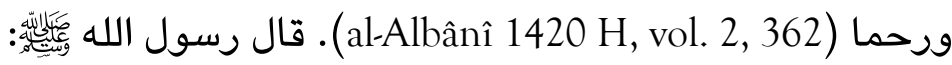

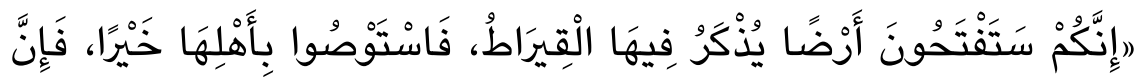

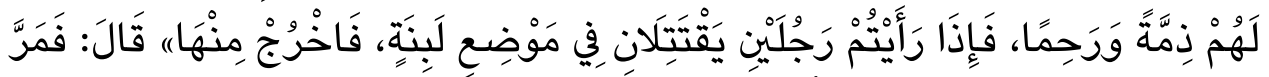

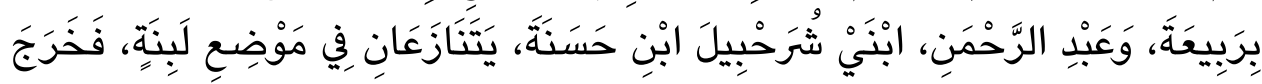

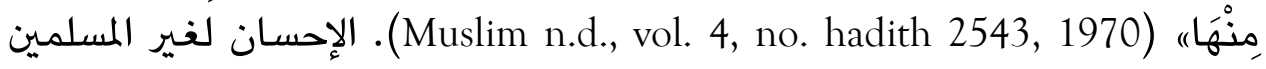


من أهل الذمة والمستأمنين ليس من الأمور النادرة بل يتجدد كل حين. السماحة في

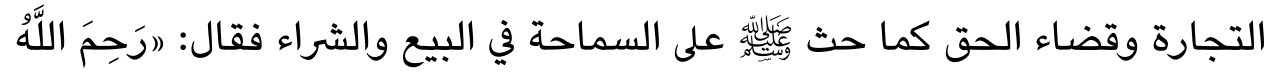

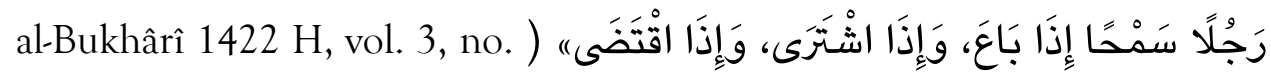

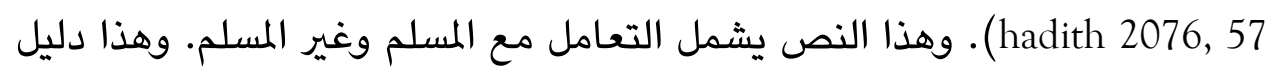

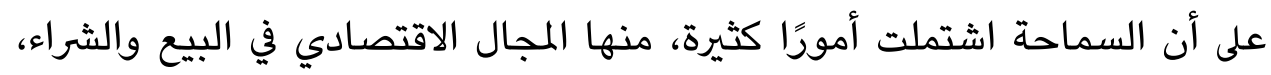
وهو أمر يتجدد يوميًا، مما يفصح أن التسامح أساس العلاقات للدولة الإسلامية.

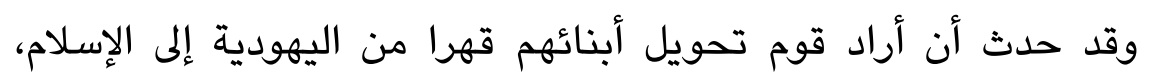

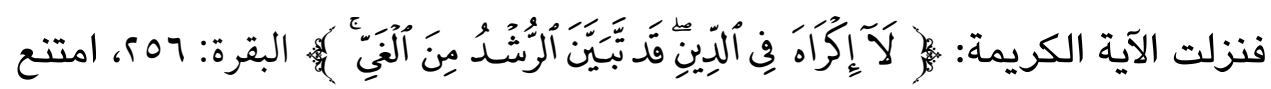
من ذلك ويقي هؤلاء على يهوديتهم رغم إسلام آبائهم (bon Kathîr 1988, vol. 1, 682). من القضايا العامة تشكل قاسما مشتركا بين المسلمين وغيرهم، ويمكن التعاون فيها، كما أن الأخطار التي تهددهم معاً ليست قليلة، ويمكن أن تشكل

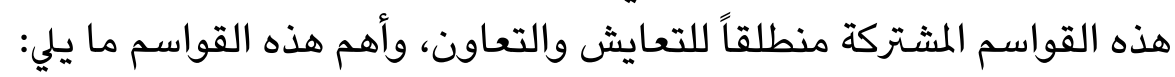

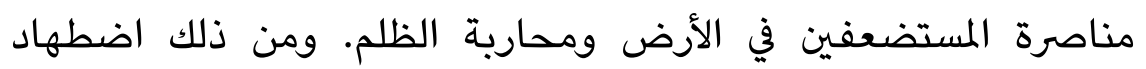

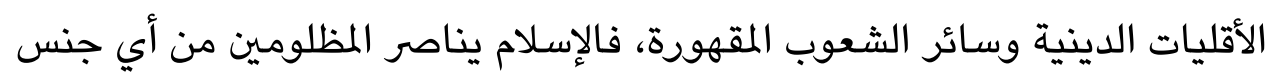

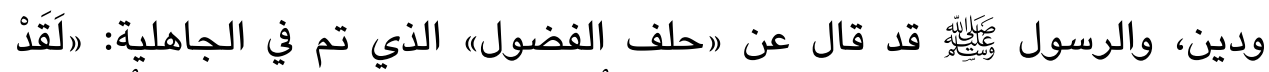

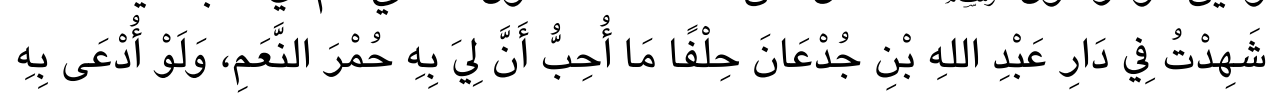

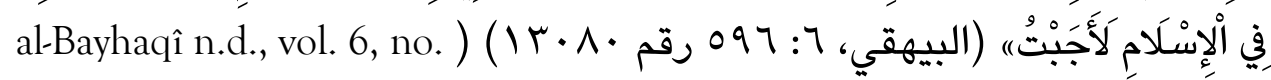
.(hadith 13080, 596 ومن أسس بناء العلاقات الخارجية للدولة الإسلامية التجارة بين الدولة،

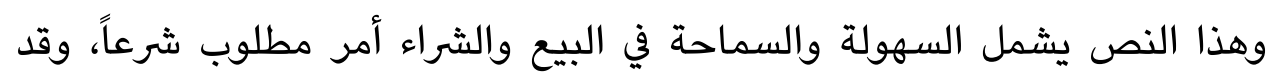

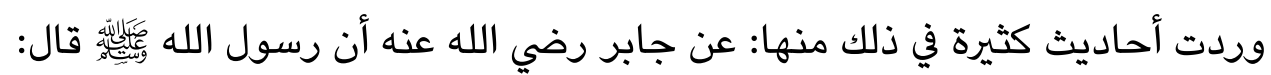

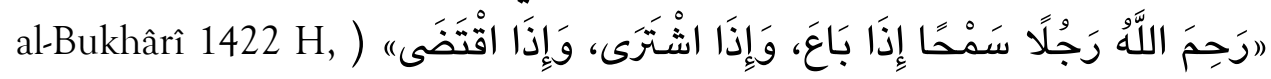

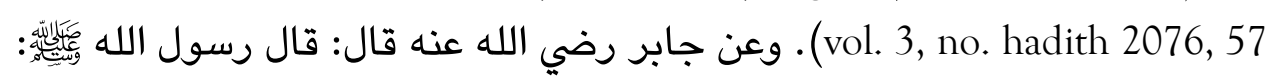

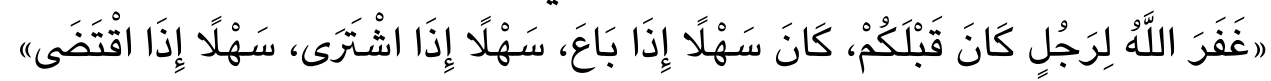

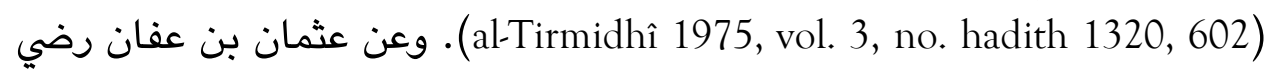




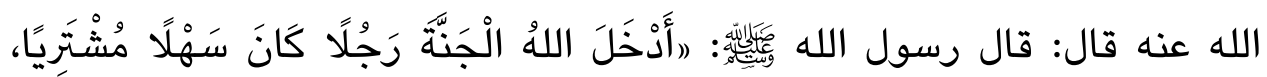

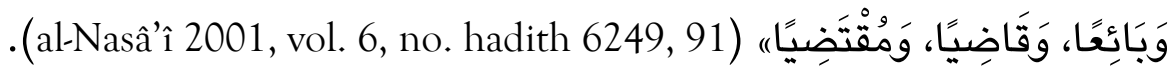

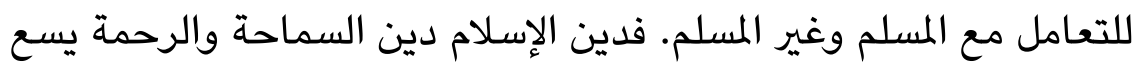
الناس كلهم ويغمرها بالرحمة والإحسان. ومن ستر مسلما ستره الله في الدنيا والآخرة، ومن فرج عن مسلم كرية من كرب الدنيا فرج الله عنه كربة من كرب يوم

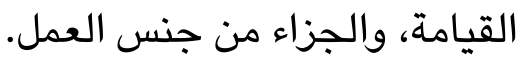

\section{تفسير الآيات التي جاءت في عالمية الدعوة وأسس بناء العلاقات الخارجية}

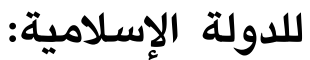

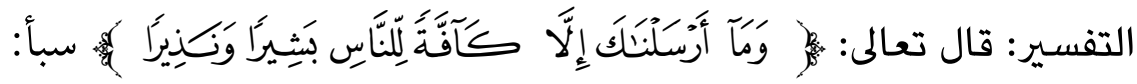

Al قال: أرسل الله محمدًا إلى العرب والعجم، فأكرمُهُم على الله أطوعهم له (al)

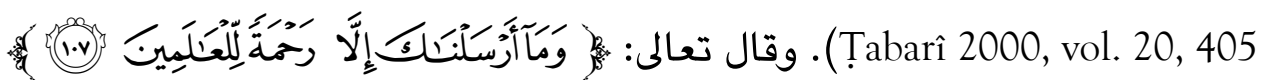

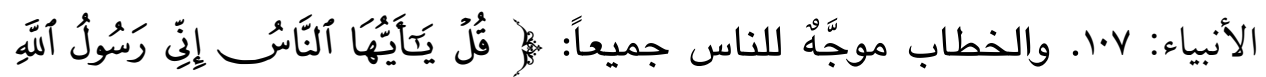

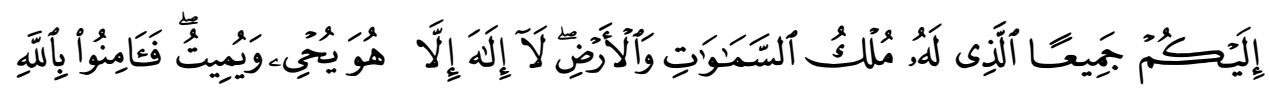

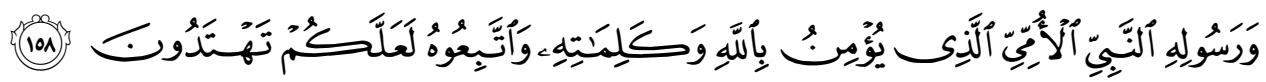
جإ الأعراف: 101، ووجه الاستدلال بهذه الآية أن لفظ (الناس) من أسماء الجموع جمع إنسان على غير لفظه واللام الداخلة عليه للجنس. قوله عز وجل: يَ) وَمَآ

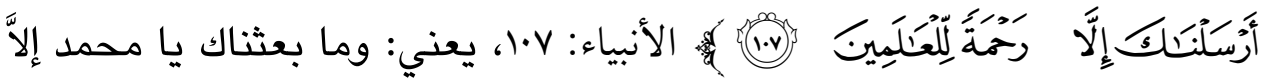

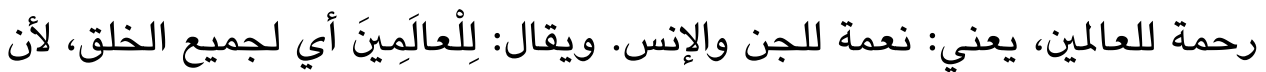
الناس كانوا ثلاثة أصناف: مؤمن، وكافر، ومنافق. وكان رحمة للمؤمنين، حيث وليث

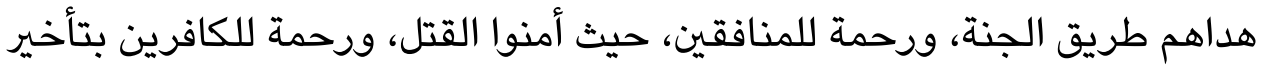
العذاب. وروى سعيد بن جبير، عن ابن عباس قال: "من آمن بالله ورسوله فله فله الرحمة في الدنيا والآخرة، وَمنَ لم يؤمن بِير، عن الله ورسوله عوفي أن يصيبه ما كان 
يصيب الأمم قبل ذلك، فهو رحمة للمؤمنين والكافرين). وذكر في الخبر: أن النبيّ

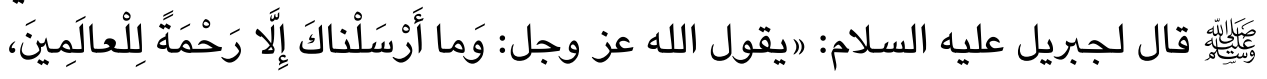
فهل أصابك من هذه الرحمة؟ قال: (رنعم أصابني من هذه الرحمة. أني كنت أخشى أخلى

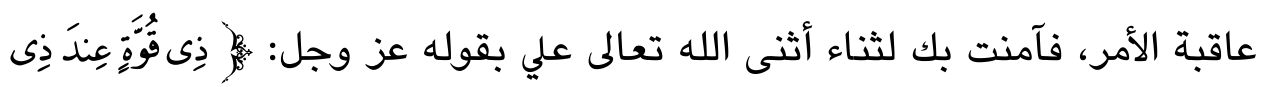

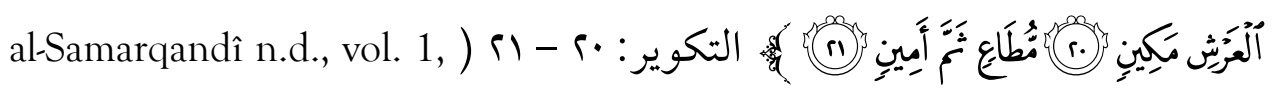

والقرآن الكريم أنزله الله تعالى ليكون ذكراً للعالمين جميعاً، وليس لأمة

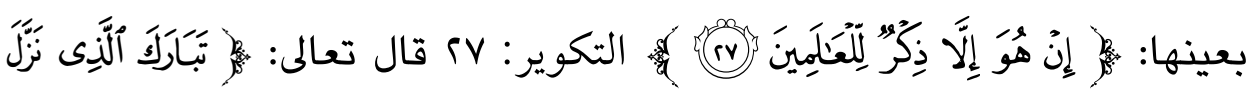

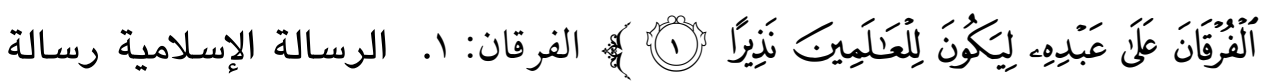

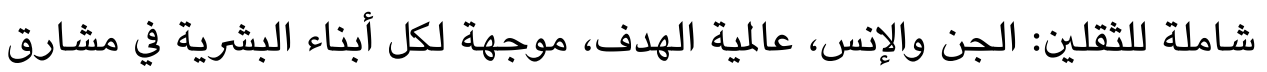

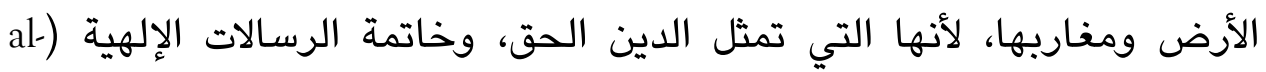

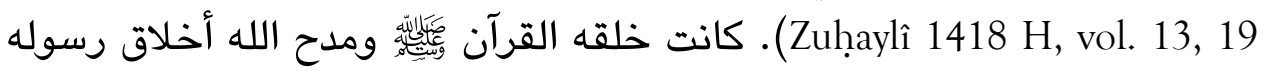

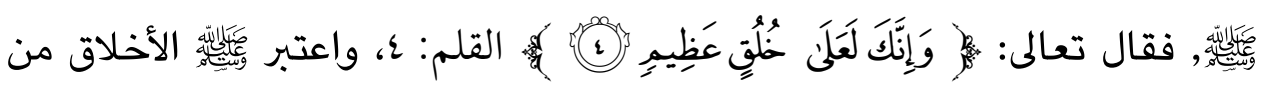

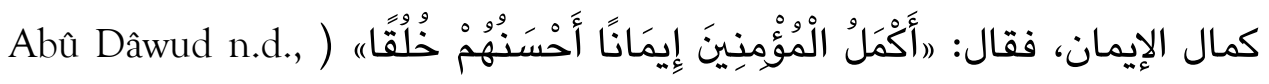

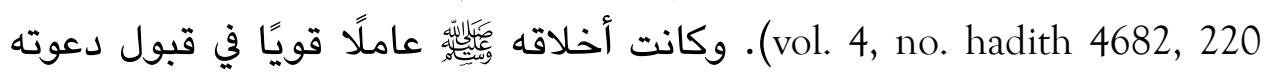

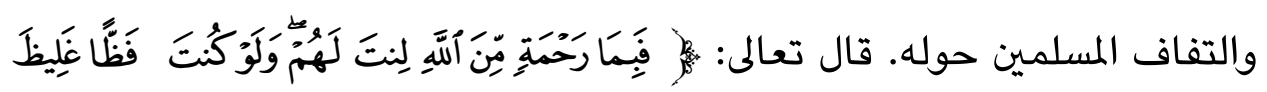

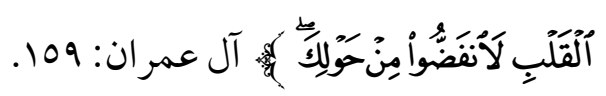

الأخلاق كلمة جامعة يؤول معناها إلى أنك إذا عرضت آئة من آئ آي القرآن

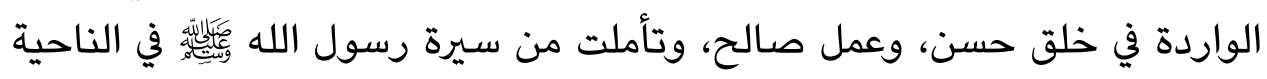

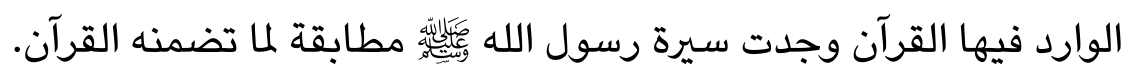

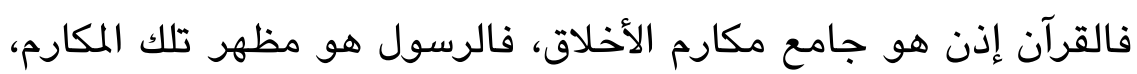

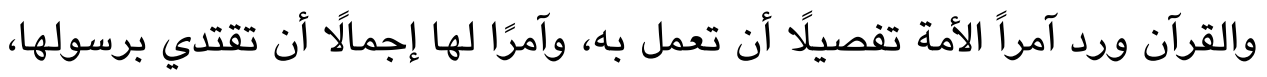

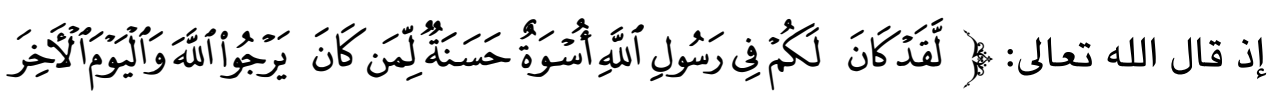




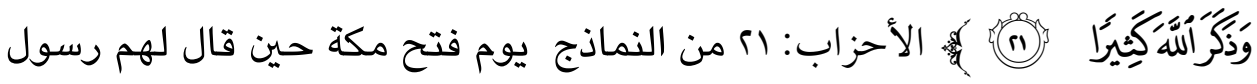
الله كريم وابن أخ كريم، قال: اذهبوا فأنتم الطلقاءه) (Ibn Hishâm n.d., vol. 4, 32).

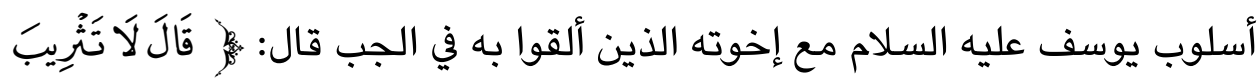

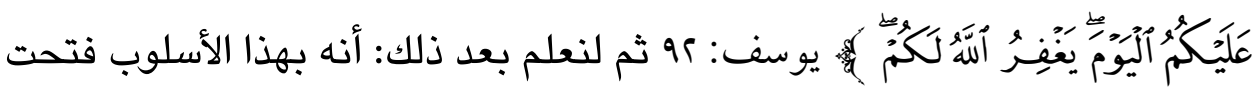

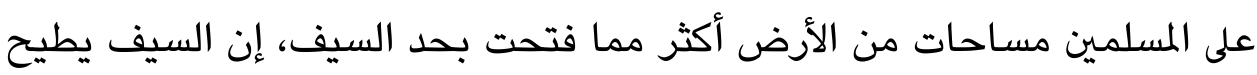

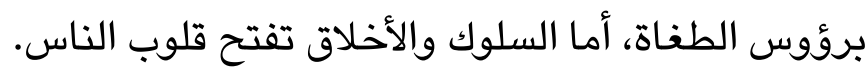

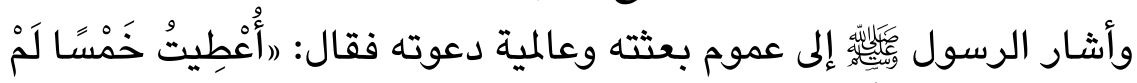

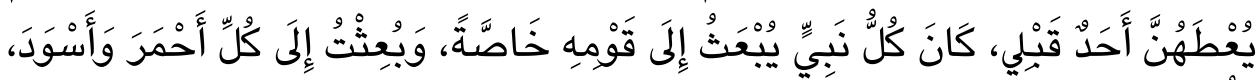

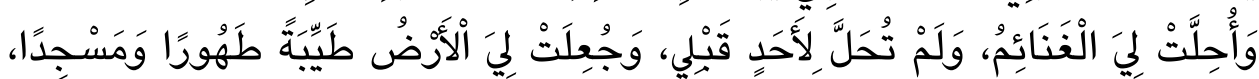

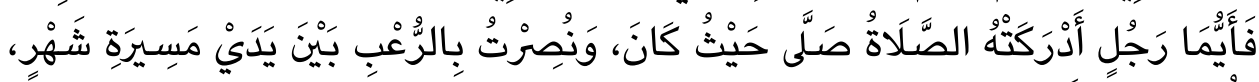

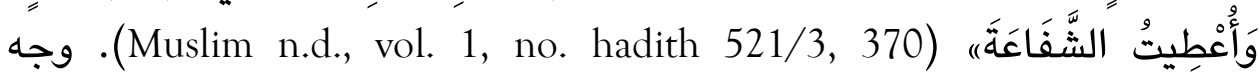
الاستدلال بهذا الحديث يدل هذا الحديث على عموم رسالته، ومما يدل على عالمية لدعوته خروجه للطائف ودعوة أهلها. وكذلك هجرته إلى المدينة المنورة. رسالة الإسلام لم تكن خاصة بجزيرة العرب إنما لجميع البلدان والأقطار في مشارقها

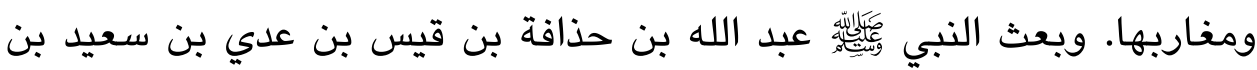

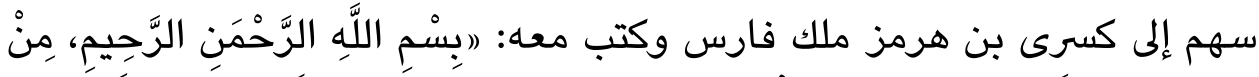

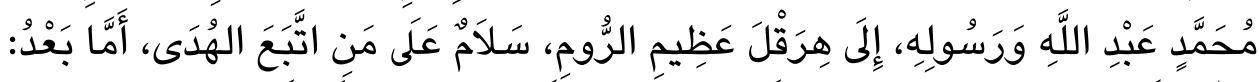

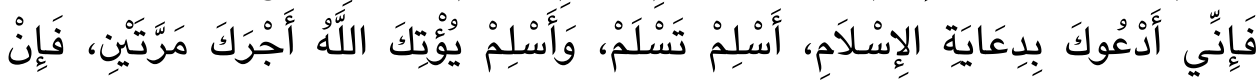

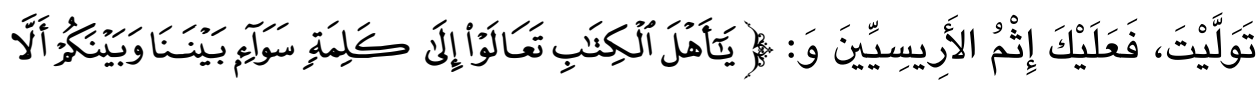

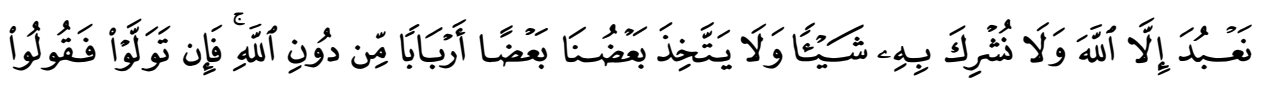

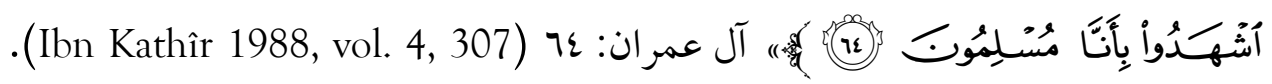

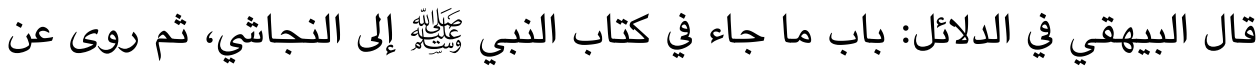

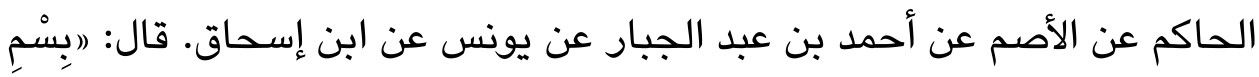




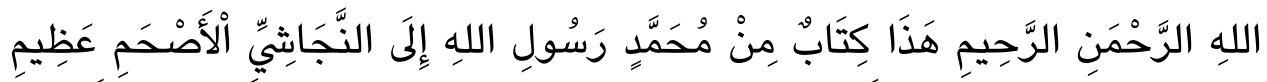

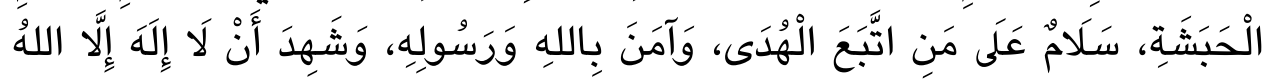

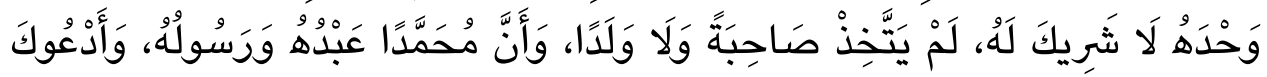

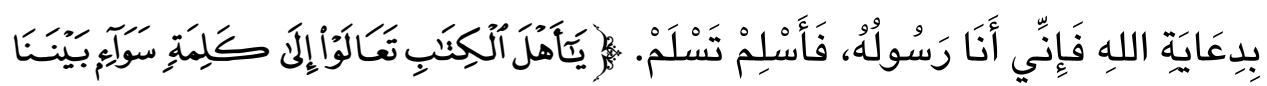

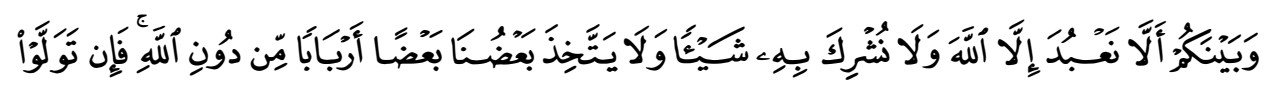

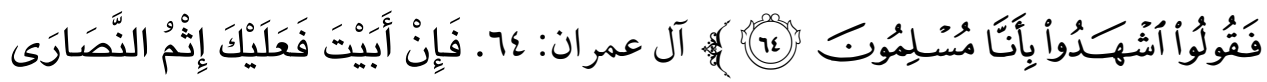

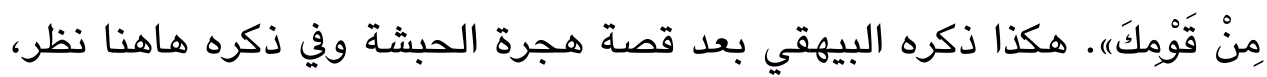

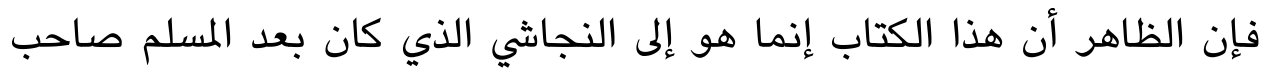

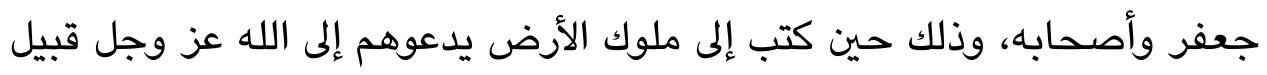

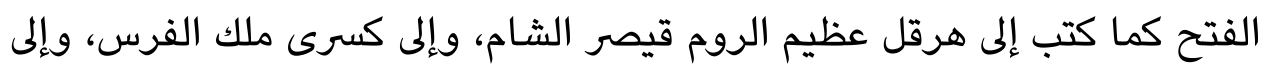
صاحب مصر، وإلى النجاشي (Ibn Kathîr 1988, vol. 3, 83).

\section{من أسس بناء العلاقات الخارجية للدولة الإسلامية وحدة الدين}

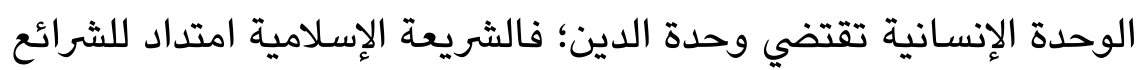

السابقة، فكل شريعة كانت مناسبة للزمان والمكان الذي الرئ أرسلت فيه، حتى إذاندا

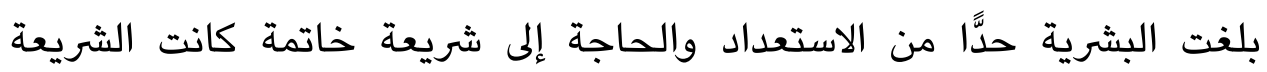

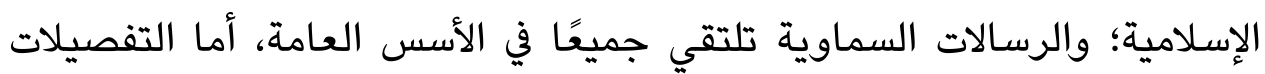

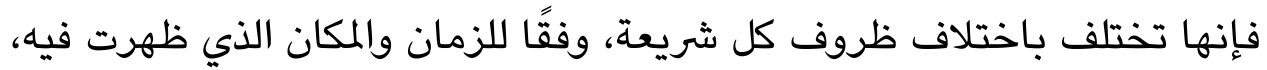

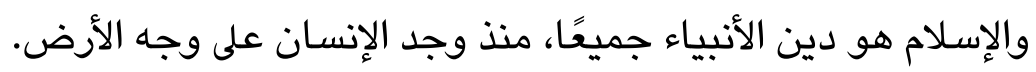

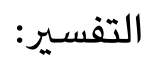

يقول تعالى:

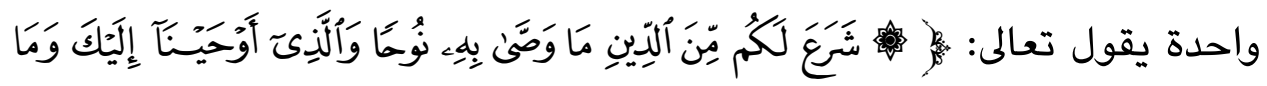

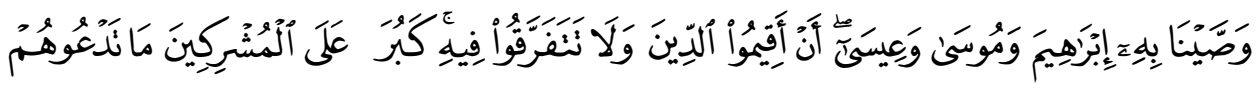

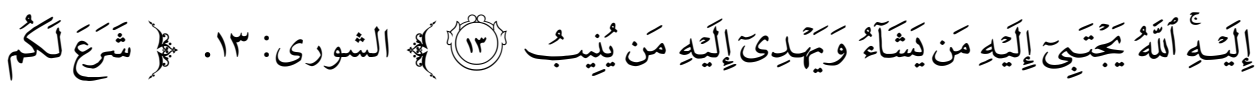




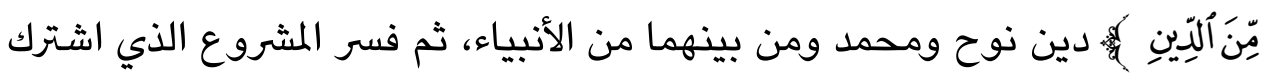

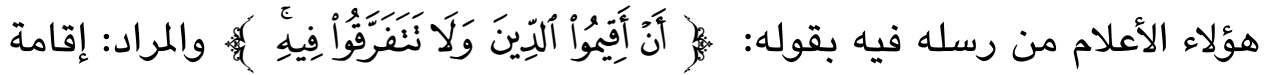

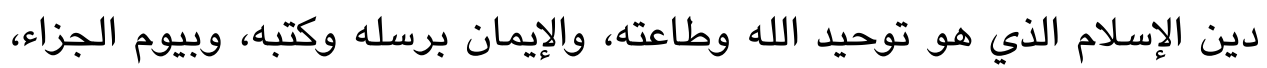

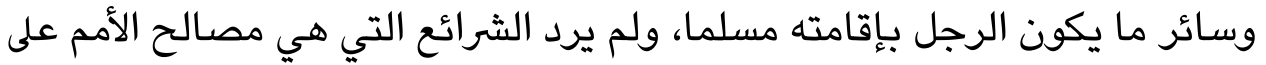

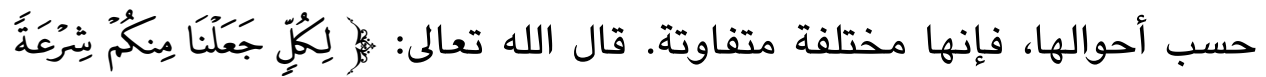

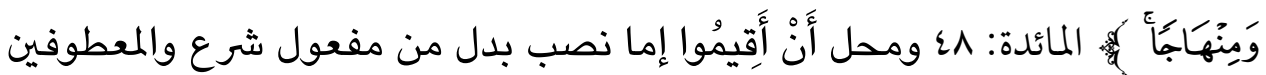
عليه، وإما رفع على الاستئناف، كأنه قيل: وما ذلك المشروع؟ فقيل: هو إقامة

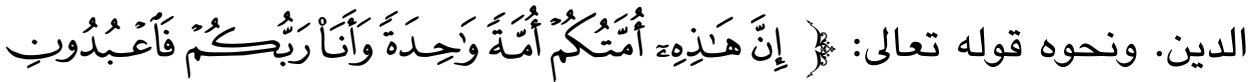

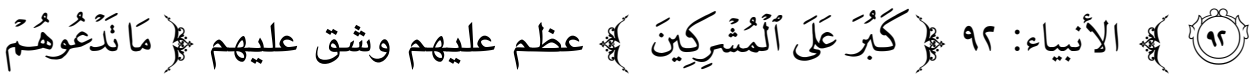

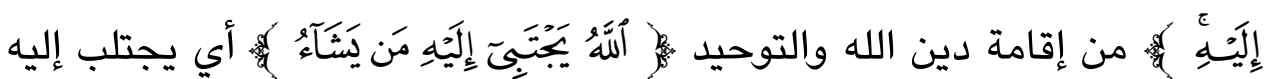

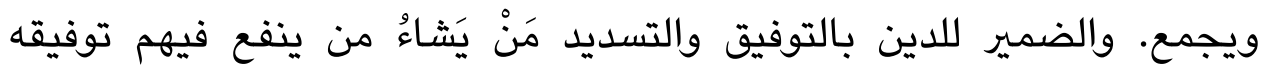

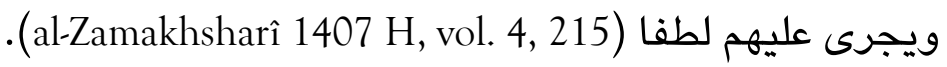
يفهم من الآيات ما يأتي:

1- إن الرسالات السماوية متحدة في أصولها، وإن اختلفت في فروعها.

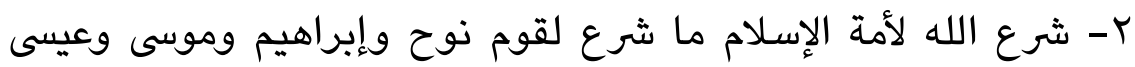
عليهم السلام، من توحيد الله وطاعته، والإيمان برسله وكتبه وياليوم الآخر، وغيرها من أصول العقيدة والعبادة والأخلاق.

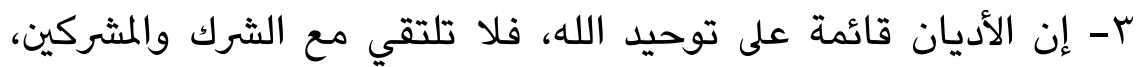
وإنما ترفض الشرك والوثنية، وتقبح عقائد المشركين، لذا كان يشق على المشركين

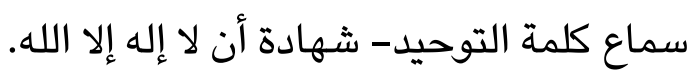

ع - يستخلص الله لدينه من رجع إليه، ويهدي إليه من وجد فيه الخير.

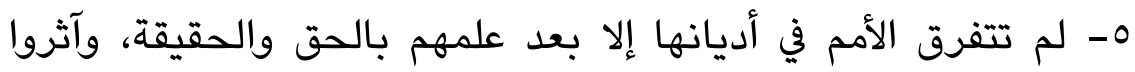
الفرقة والاختلاف على الوحدة والجماعة للبني والظلم والاشتخال بالدنيا، فما على 
المسلمين إلا أن يحذروا الفرقة والتشتت ويحرصون على الجماعة والوحدة، ينبذوا الخلافات والعصبيات المذهبية الضارة. 7- اقتضت الحكمة الإلهية تأخير العذاب إلى يوم القيامة، وتأخير الفصل بين المتلفين إلى يوم المعاد والحساب.

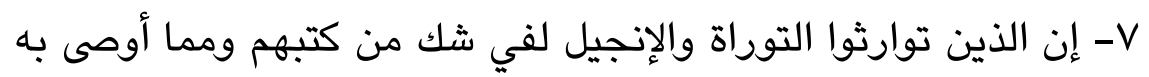

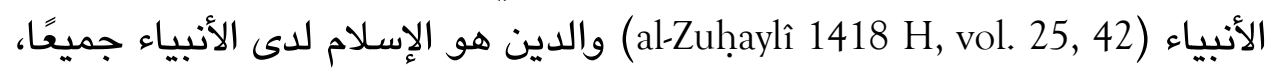
يقول تعالى:

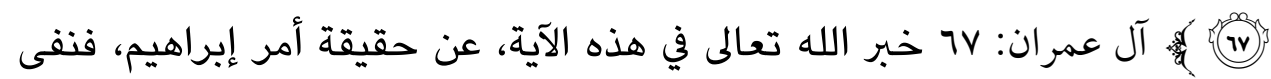

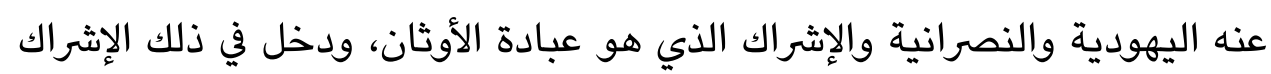

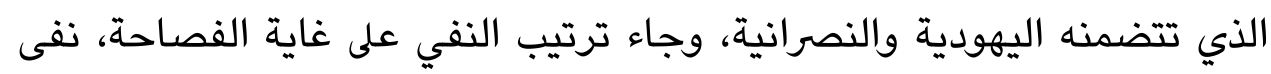

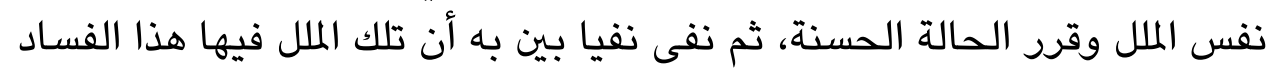

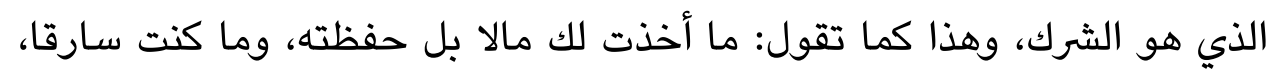

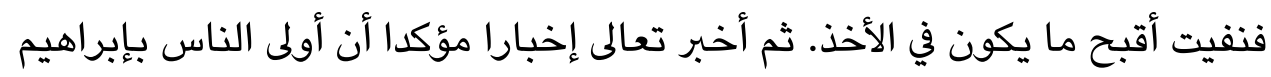

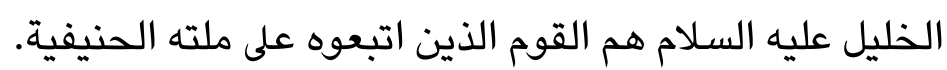

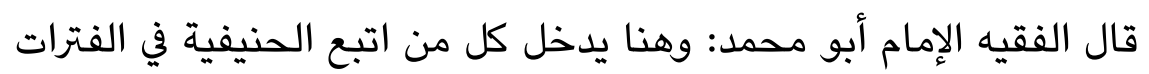

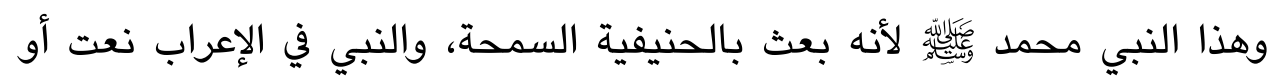

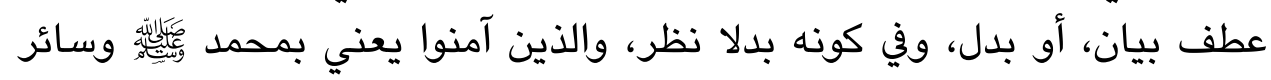

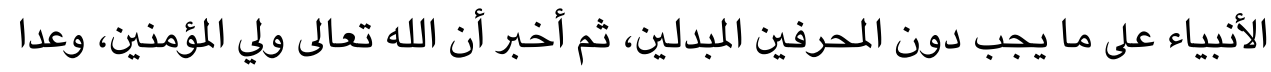
منه لهم بالنصر في الدنيا والنعيم في الآخرة (Ibn 'Ativah 1422 H, vol. 1, 451).

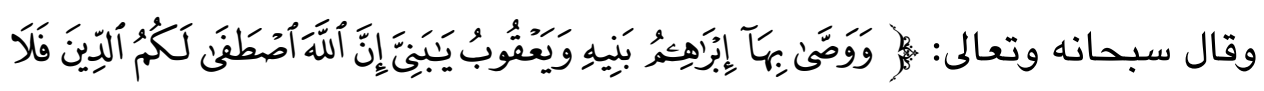

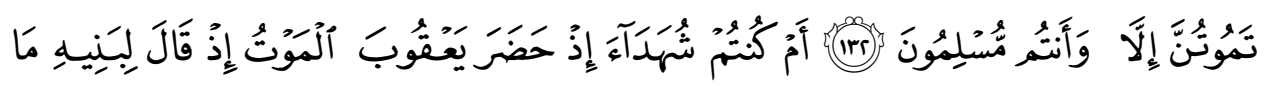

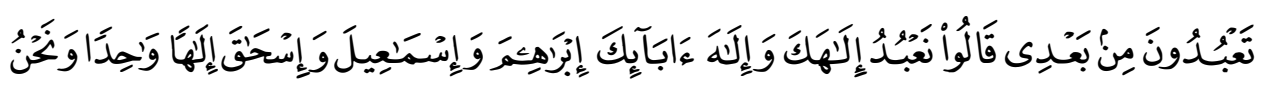

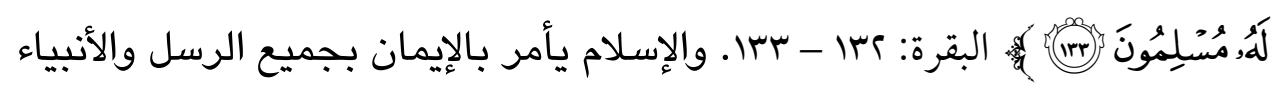

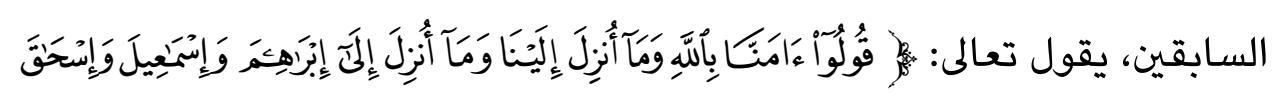




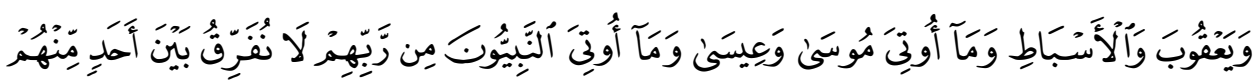

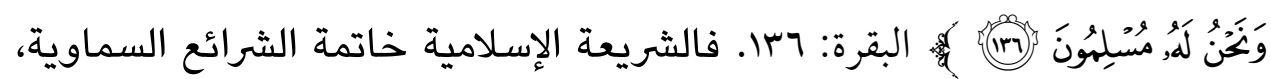
جاءت لسعادة البشرية التي كانت متعطشة إليها؛ لإنقاذها مما تعانيه، وإخراجها من ظلمات الجهالة إلى نور الهداية.

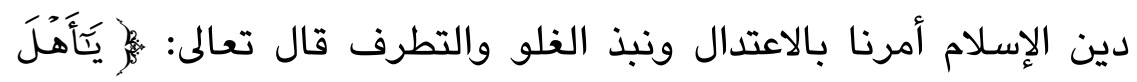

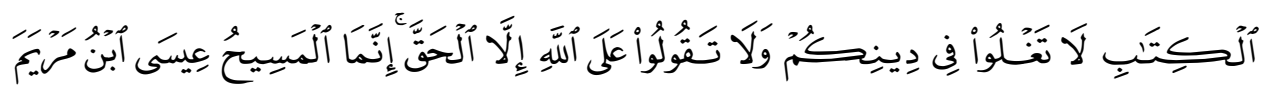

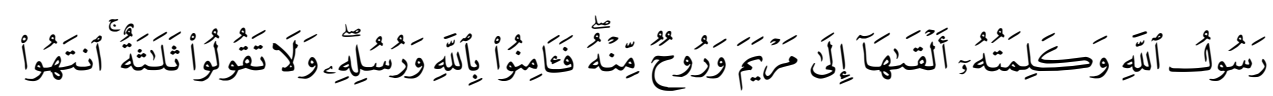

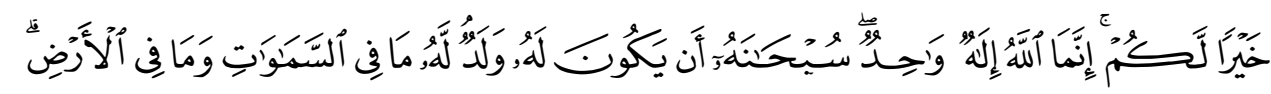

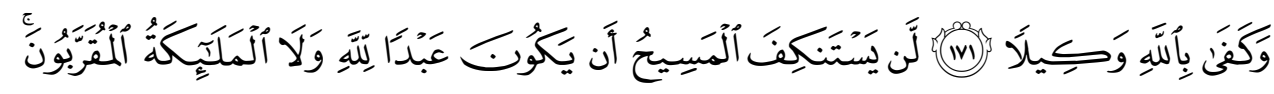

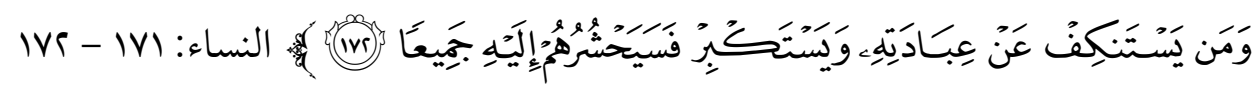

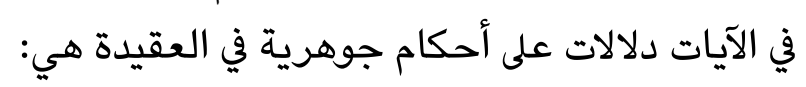

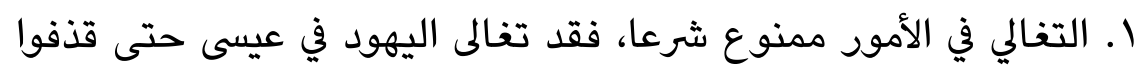

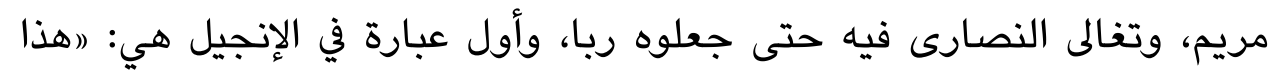

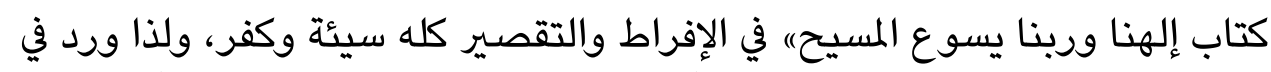

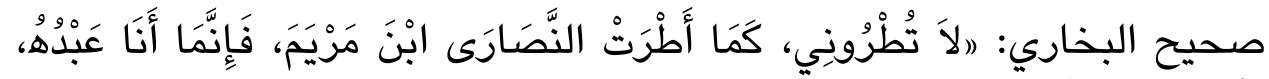

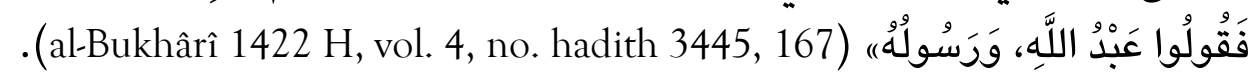

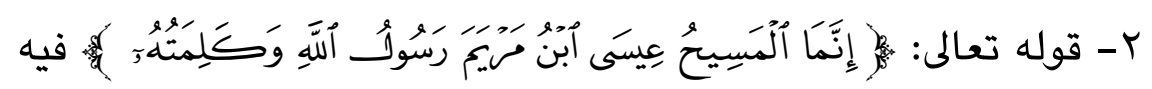

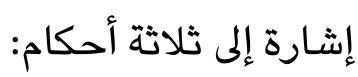

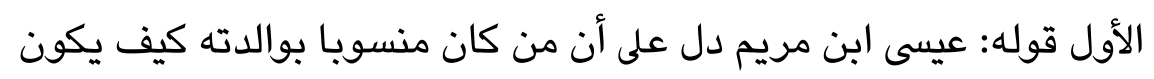

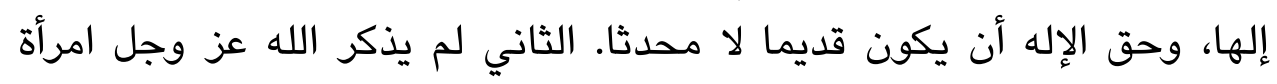

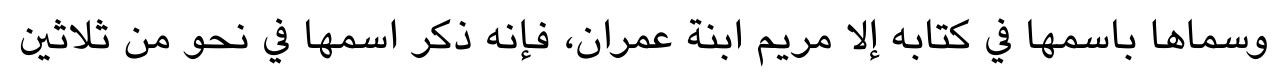

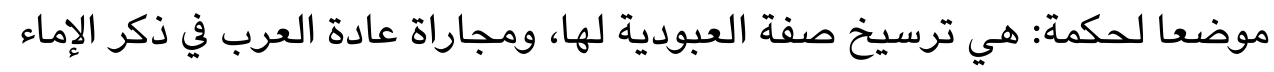


بأسمائهن، أما الحرائر فكانوا يصونون أسماءهن عن الذكر والتصريح بها، لئلا تبتذل أسماؤهن. الثالث اعتقاد أن عيسى عليه السلام لا أب له واجب، فإذا تكرر اسمه الأبه

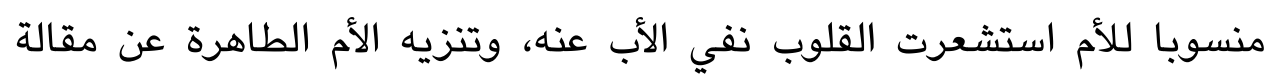

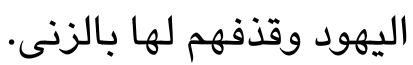

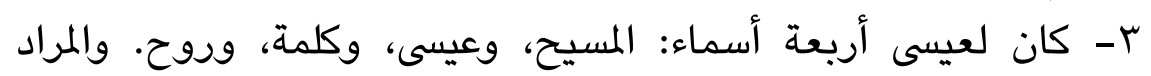

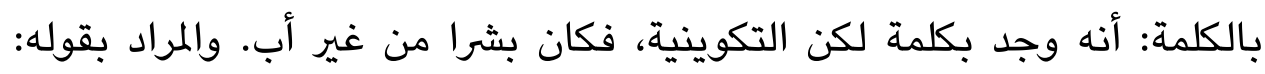

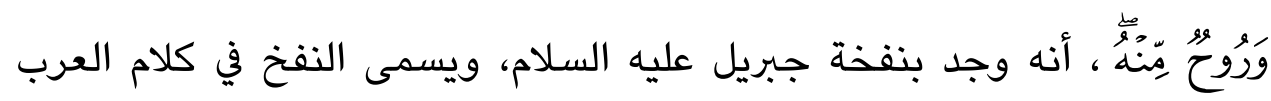

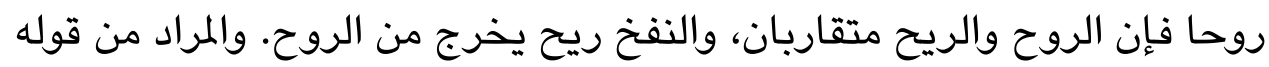

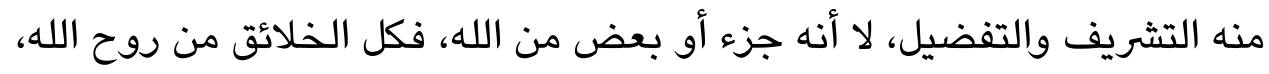

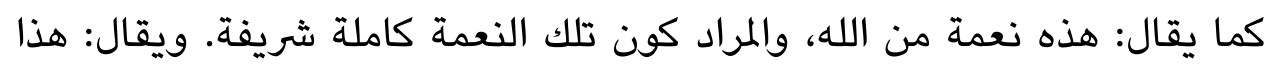

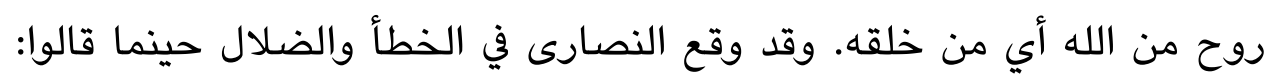
عيسى جزء من الله لأنه روح من الله الله. ع- الإيمان بأن الله إله واحد خاله الله المانه المسيح ومرسلة، ويأن الرسل ومنهم

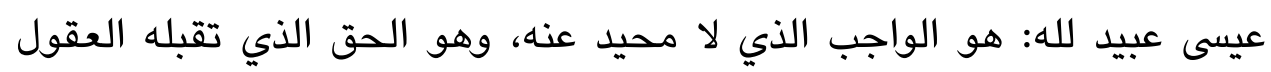
الرشيدة، فلا يصح جعل عيسى إلها.

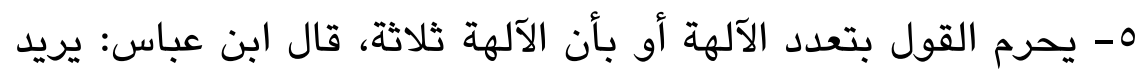

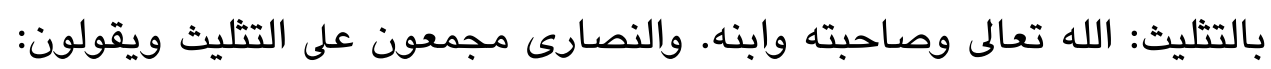

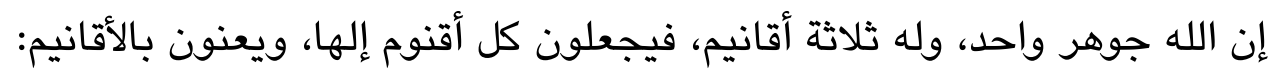

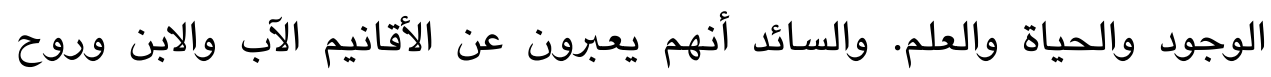

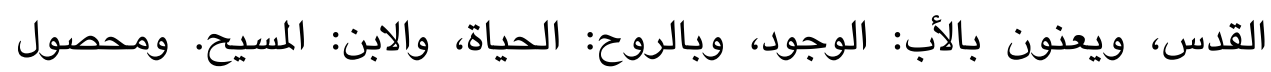

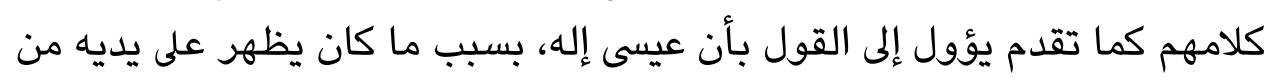

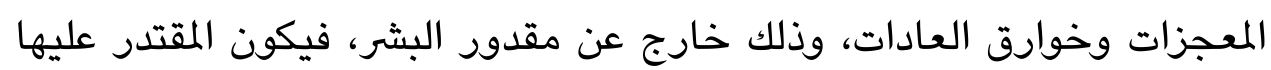

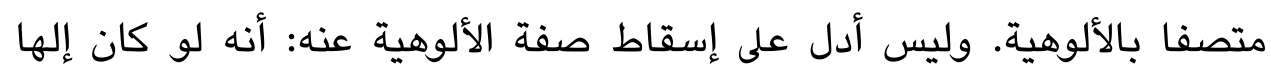
لخلص نفسه من أعدائه، ودفع شرهم، ولم يمكنهم من صلبه، كما يزعمون. 
7- الانتهاء عن القول بالتثليث هو الخير المحض، وهو الصواب لأن الله إله

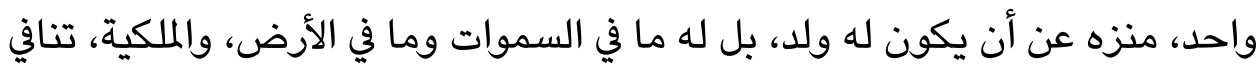
البنوة، فلا شريك له، وعيسى ومريم من جملة ما في السموات وما في في الأرض، ومات وما ولها

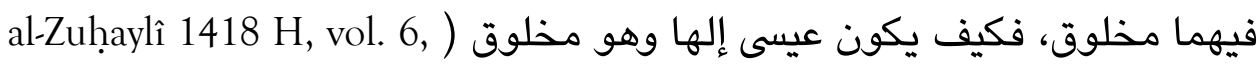

سواء كان في فهمه أو في تطبيقه، والغلو آفة عظيمة مهلكة؛ فعن ابن

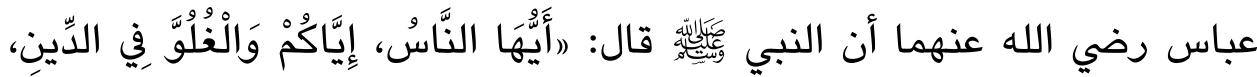

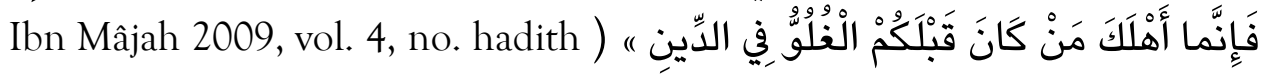
3029, 228 . يقول محمد بن نصر المروزي رحمه الله : (وهكذا عامة أهل الأهواء والبدع إنما هم بين أمرين غلو في دين الله وشدة ذهاب فيه حتى مرقى مرقوا منه

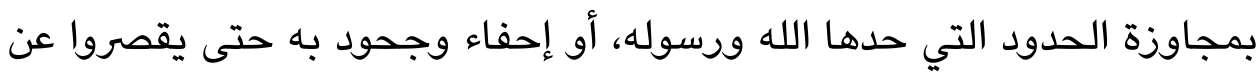
حدود الله التي حدها ودين الله موضوع فوق التقصير ودون الغلو) والله تعالى

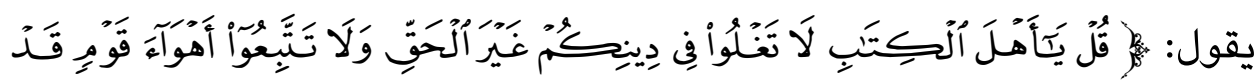

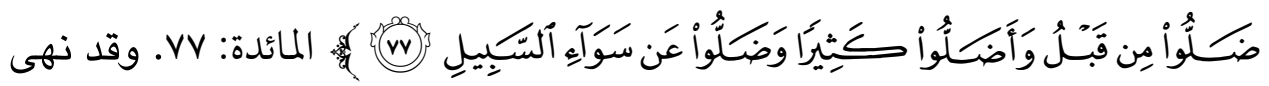

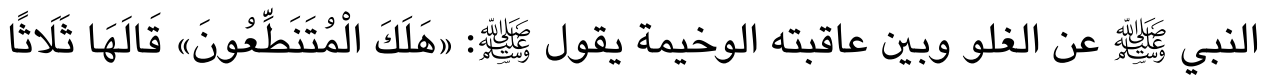

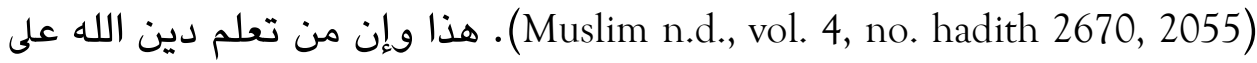

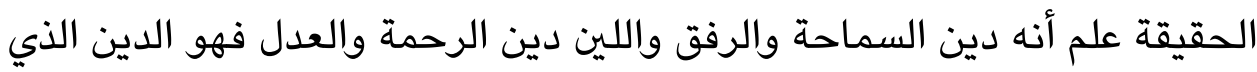

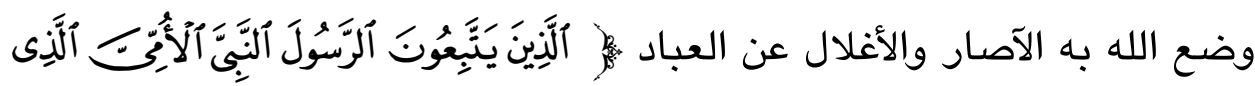

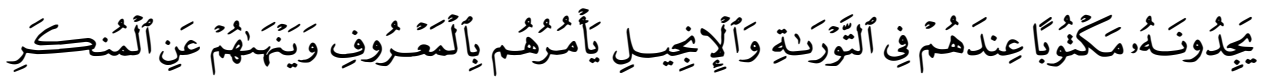

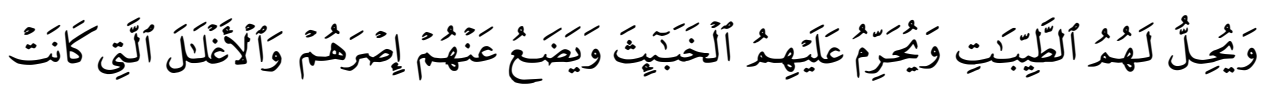

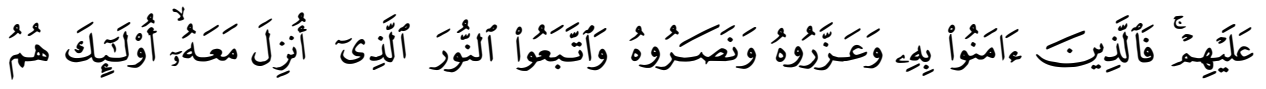

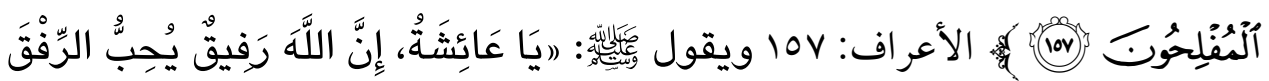

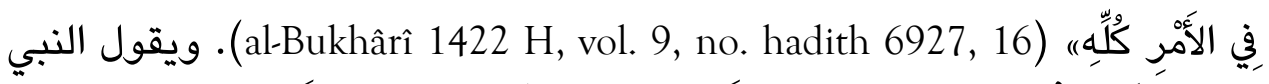

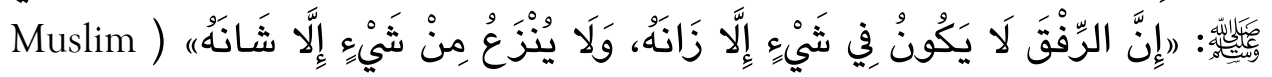




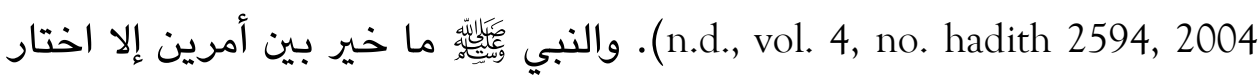

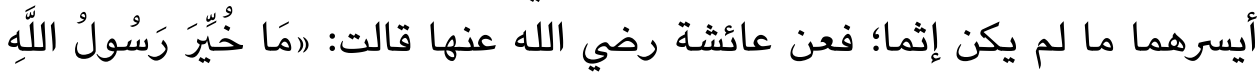

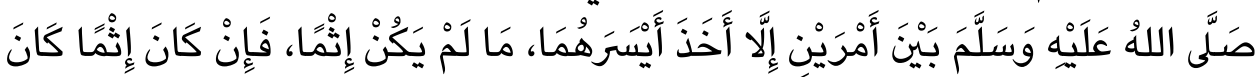

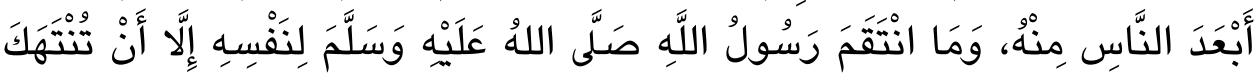

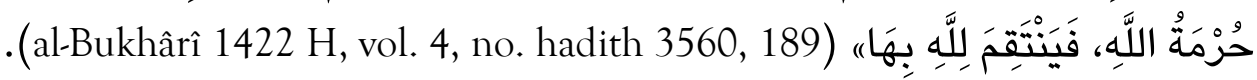

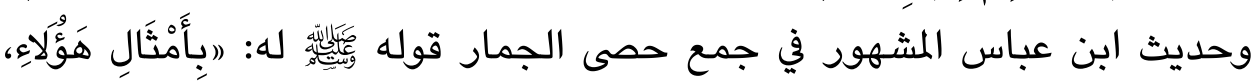

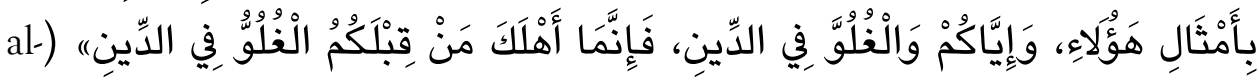
.(Nasầî 2001, vol. 4, no. hadith 4049, 178

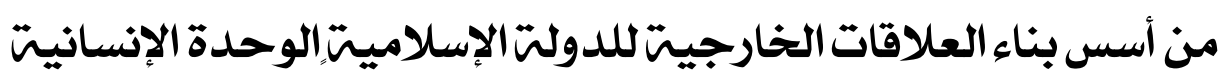

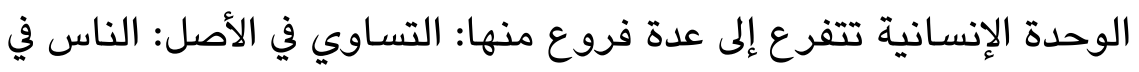

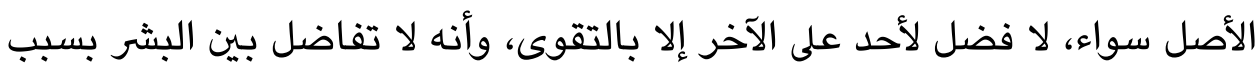

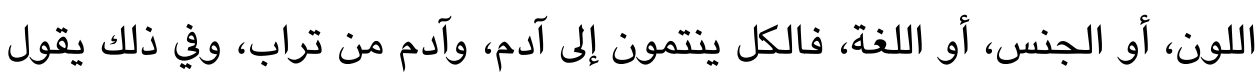

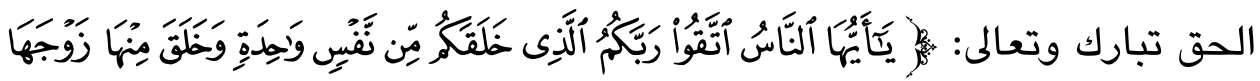

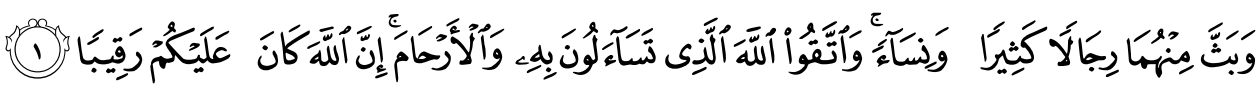

$$
\text { التفسير : }
$$

فقد دلت الآية الكريمة على أن الخالق واحد، والنفس الإنسانية واحِدَةٍ آدم

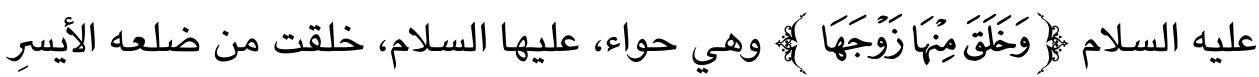

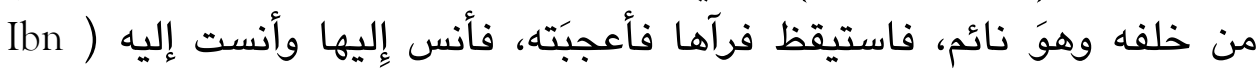
(Kathîr 1999, vol. 2, 206

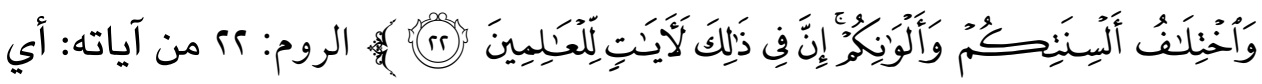

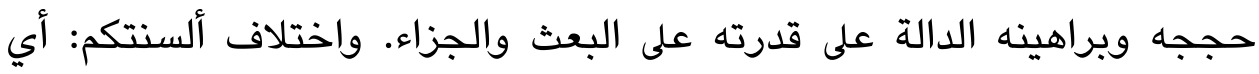

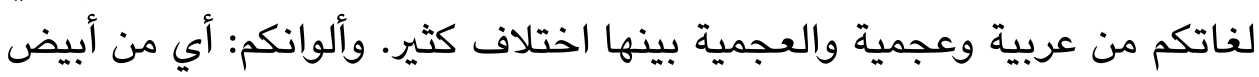


وأصفر وأحمر وأسود والكل أبناء رجل واحد وامرأة واحدة. للعالمين: أي للعقلاء

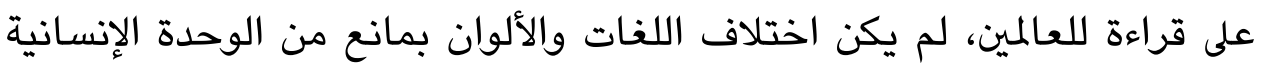

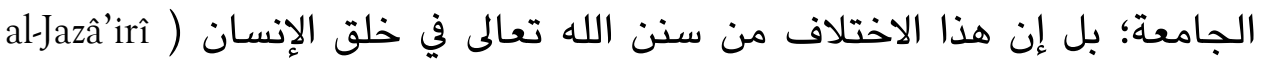
(2003, vol. 4, 170 . ويقول الحق تبارك وتعالى:

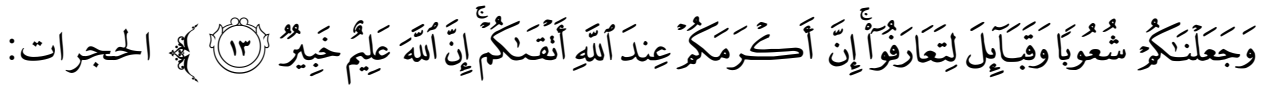

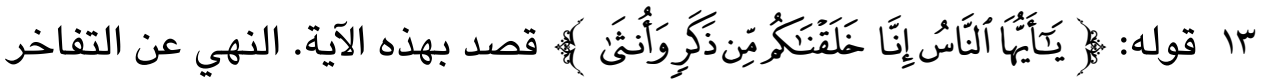
بالأنساب، وبين التساوي فيها بأن خلقهم من ذكر وأنثى يعني آدم وحواء. ثم قال:

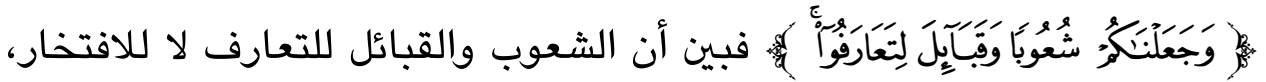
وفيها ثلاثة أوجه: أحدها: أن الشعوب النسب الأبعد والقبائل النسب الأقرب , قاله مجاهد , وقتادة. وقال الشاعر:

(قبائل من شعوب ليس فيهم ... كريم قد يعد ولا نجيب) وسموا شعوياً

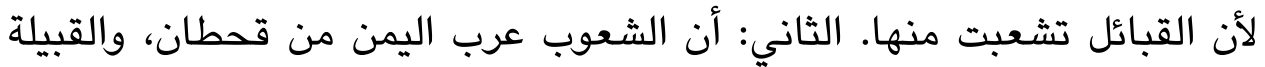
ربيعة ومضر وسائر عدنان. الثالث: أن الشعوب بطون العجم، والقبائل بطون العرب. ويحتمل رابعاً: أن الشعوب هم المضافون ودئر إلى النواحي والشعاب، والقبائل

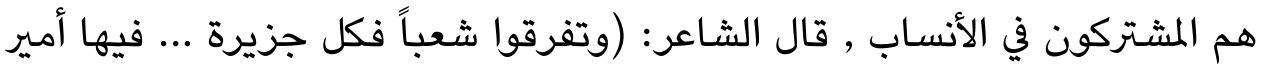

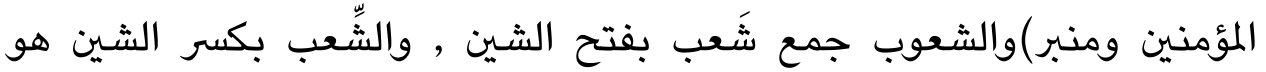

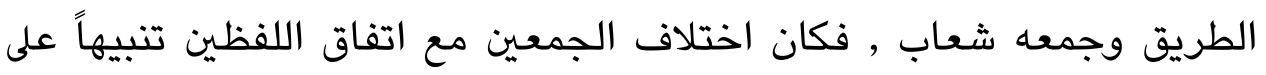

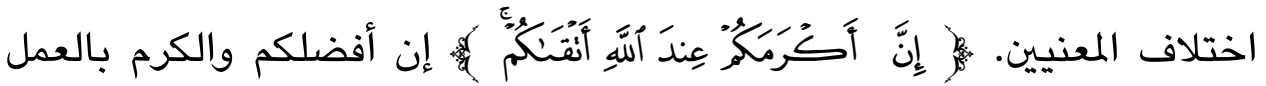
والتقوى لا بالنسب (al-Mâwardî n.d., vol. 5, 336).

الخلاصة

الحمد لله الذي بنعمته تتم الصالحات وأشهد أن لا إله إلا الله وحده لا

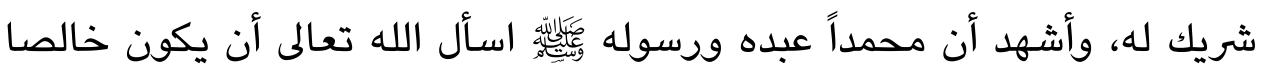
لوجه الكريم إنه جواد كريم. 
من خلال تتبع هذه الدراسة نستطيع الوقوف على أهم النتائج التي

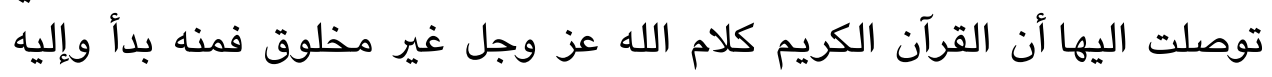
يعود ومعجزة خالدة. 1 / أن السلم الدعوي والسلام دعوة الأنبياء والرسل عليهم الصلاة والسلام

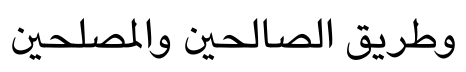
r/ الأصل في علاقة المسلمين بغيرهم هو السلم والدعوة وليس الحرب ولا

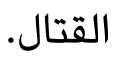

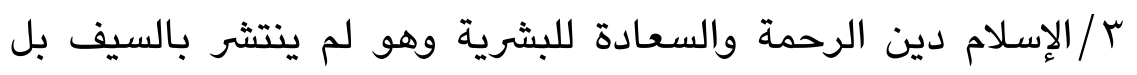
بالدعوة والبرهان والحجة والحكمة والموعظة الحسنة.

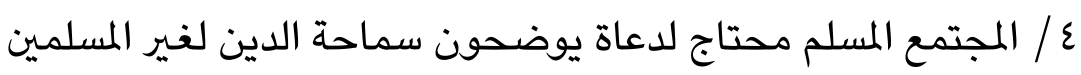

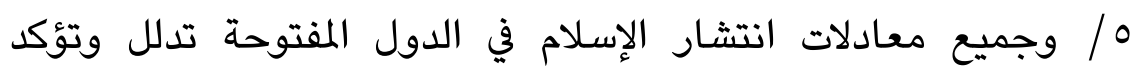

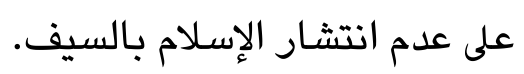
7/ الإسلام يدعو إلى اللين في إبلاغ دعوته، بل يدعو للتسامح حتى مع اللفاء

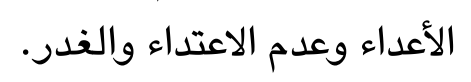

$$
\text { التوصيات: أما التوصيات فأوصي بالتالي: الفدر. }
$$

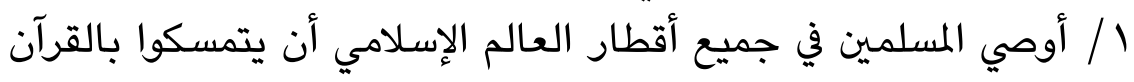

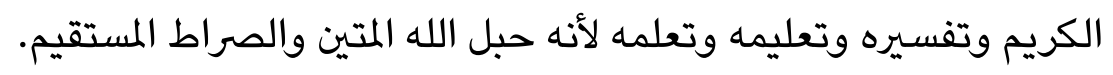

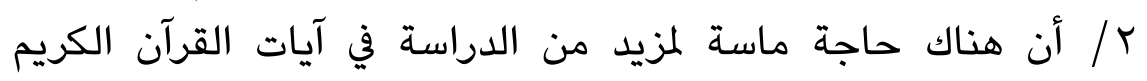

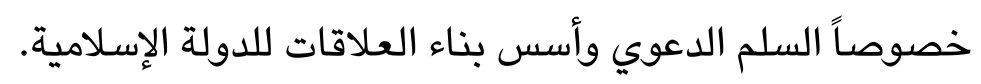

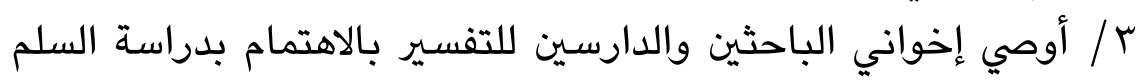

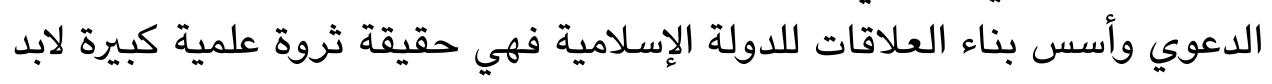

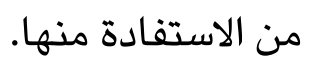
هذه أبرز نتائج البحث وما توصلت إليه، أسأل الله القبول والسداد وأطلبه الأجر والثواب وآخر دعوانا أن الحمد لله رب العائه المين. 


\section{References}

Abû Dâwud, Sulaymân ibn al-Ash'ath ibn Ishâq ibn Bashîr ibn Shadâd ibn 'Amr al-Azadî al-Sijistânî. n.d. Sunan Abî Dâwud, ed. Muḥammad Muhy al-Dîn Abû al-Hamîd. Beirut: al-Maktabah al-Hadîthiyah.

Aḥmad ibn Hanbal, Abû 'Abd Allâh Aḥmad ibn Muḥammad ibn Ḥanbal ibn Hilâl ibn Asad al-Shaybânî. 2001. Musnad al-Imâm Aḥmad ibn Hanbal, ed. Shu'ayb al-Arnawt. Beirut: Mu'assasah al-Risâlah.

al-Albânî, Abû 'Abd al-Raḥmân Muhạmmad Nâșir al-Dîn. 1420 H. Silsilah al-Ahâdith al-Sahîhah wa Shay' min Fiqhihâ wa Fawâ'idihâ. Riyad: Maktabah al-Ma ârif li al-Nashr wa al-Tawzî‘.

al-Asfahânî, Abû al-Qâsim al-Ḥusayn Muḥammad al-Râghib. 1412 H. alMufradât fî Gharîb al-Qur'ân, ed. Șafwân 'Adnân al-Dâwudî. Beirut: Dâr al-Qalam.

al-Baghawî, Abû Muhammad al-Husayn ibn Mas'ûd ibn Muhammad ibn alFarâ'. 1420 H. Ma'âlim al-Tanzîl fî Tafsîr al-Qur'ân, ed. 'Abd al-Razzâq al-Mahdî. Beirut: Dâr Ihỵâ' al-Turâth al-'Arabî.

al-Bukhârî, Abû 'Abd Allâh Muhammad ibn Ismâ'îl al-Ja'fî. 1422 H. Sahîh al-Bukhârî, ed. Muhạmmad Zuhayr Nașîr al-Nâșir. Lebanon: Dâr alHuffâz.

al-Fârâbî, Abû Ibrâhîm Ishâa al-Ḥusayn. 2003. Mu'jam Dîwân al-Adab, ed. Aḥmad Mukhtâr 'Umar. Cairo: Mu'assasah Dâr al-Shu'b li alȘihâfah al-Ṭiba'ah al-Nashr.

al-Fârâbî, Abû Naṣr Ismâ'îl Hammâd al-Jawharî. 1987. al-Sihhâh Tâj alLughah wa al-Sihhâh al-'Arabiyyah, ed. Aḥmad 'Abd al-Ghafûr 'Atțâr. Beirut: Dâr al-'Ilm li al-Malâyîn.

al-Farâhîdî, Abû 'Abd al-Raḥmân al-Khalîl ibn Aḥmad. n.d. al-Ayn, eds. Mahdî al-Makhzûmî and Ibrâhîm al-Samrî̀î. Lebanon: Dâr wa Maktabah al-Hilâl.

al-Hâkim al-Naysâbûrî, Muhammad 'Abd Allâh Muhammad Hamûdiyah Na'îm. 1990. al-Mustadrak 'alâ al-Sahihayn, ed. Musțafâ 'Abd al-Qadîr 'Attâ. Beirut: Dâr al-Kutub al-'Ilmiyah. 
Ibn 'Ațiyah, Abû Muhammad 'Abd al-Haqq ibn Ghâlib ibn 'Abd alRaḥmân ibn Tammâm ibn 'Ațiyah al-Andalûsî. 1422 H. al-Kitâb al'Azîz, ed. 'Abd al-Salâm 'Abd al-Shâfî Muhạmmad. Beirut: Dâr alKutub al-'Ilmiyah.

Ibn al-Jawzî, Abû al-Faraj Jamâl al-Dîn 'Abd Rahmân ibn 'Alî ibn Muhammad. 1422 H. Zâd al-Maysir fì 'Ilm al-Tafsîr, ed. 'Abd alRazzâq al-Mahdî. Lebanon: Dâr Kitâb al-'Arabî.

Ibn Fâris, Abû al-Husayn Aḥmad ibn Fâris ibn Zakariyâ al-Qazwaynî al-Râzî. 1979. Mu'jam Maqâyis al-Lughah, ed. 'Abd al-Salam Muhammad Hârûn. Damascus: Dâr al-Fikr.

Ibn Fâris, Abû al-Husayn Aḥmad ibn Fâris ibn Zakariyâ al-Qazwaynî al-Râzî. 1986. Mujmal al-Lughah li Ibn Fâris, ed. Zuhayr 'Abd al-Muhsin Sultân. Beirut: Mu'assasah al-Risâlah.

Ibn Hishâm, Abû Muhammad Jamâl al-Dîn 'Abd al-Mâlik ibn Hishâm ibn Ayûb al-Himyarî al-Ma'âfrî. n.d. al-Sîrah al-Nabawiyah, ed. Taha 'Abd al-Ra'ûf Sa'ad. Beirut: Dâr al-Jayl.

Ibn Kathîr, Abû al-Fidâ’ Ismâ'îl ibn 'Umar ibn Kathîr al-Qurashî al-Bașrî. 1988. al-Bidâyah wa al-Nihâyah, ed. 'Alî Shîrî. Beirut: Dâr Ihyyâ' alTurâth al-'Arabî.

Ibn Kathîr, Abû al-Fidâ' Ismâ'îl ibn 'Umar ibn Kathîr al-Qurashî al-Bașrî. 1999. Tafsîr al-Qur'ân al-'Ažîm, ed. Sâmî ibn Muhammad Salâmah. Riyad: Dâr Taybah li al-Nashr wa al-Tawzî‘.

Ibn Taymiyah, Taqî al-Dîn Abû al-Abbâs Ahmmad ibn 'Abd al-Halîm. 1995. Fatâwâ Shaykh al-Islâm Ibn Taymiyah, ed. 'Abd al-Raḥmân Muhammad Qâsim. Medina: Majma' Malik Fahd li al-Ṭibâ‘ah alMuṣhạaf al-Sharîf.

al-Jazâ’irî, Abû Bakr Jâbir ibn Mûsâ ibn 'Abd al-Qâdir ibn Jâbir. 2003. Aysar al-Tafâsir li Kalâm al-'Alî al-Kabîr. Medina: al-Mamlakah al-'Arabiyah al-Su'ûdiyah al-Taybah.

Khallâf, 'Abd al-Wahhâb. 1988. 'Ilm Ușûl al-Fiqh. Beirut: Dâr al-Kutub al'Ilmiyah. 
al-Mâwardî, Abû al-Hasan 'Alî ibn Muhammad al-Baghdâdî. n.d. Tafsîr alMâwardî al-Nukat wa al-'Uyûn, ed. al-Sayyid ibn 'Abd al-Maqșûd ibn 'Abd al-Rahîm. Beirut: Dâr al-Kutub al-'Ilmiyah.

Muslim ibn al-Hajjâj, Abû al-Hasan al-Qushayrî al-Naysâbûrî. n.d. al-Musnad al-Sahîh, ed. Muhammad Fu'âd 'Abd al-Bâqî. Beirut: Dâr Ihyâ' alTurâth al-'Arabî.

al-Qayruwânî, Abû Muhammad Makkî ibn Abî Ṭâlib Ḥamûsh ibn Muhammad ibn Mukhtâr al-Qaysî. 2008. al-Hidâyah ilâ Bulûgh alNihâyah fì 'Ilm Ma'ân al-Qur'ân wa Tafsîrihi wa Ahkâmihi wa Jumal min Funûn 'Ulûmihi, ed. Collection of theses at the college of graduate studies and scientific research University of Alshariqa under supervision A.P: Alshahid Albushekhi. United Arab Emirate: Quran and Sunnah Researches, College of Legislation and Islamic Studies, University of Alshariqa.

al-Sa'dî, 'Abd al-Raḥmân ibn Nâsir ibn 'Abd Allâh. 2000. Taysîr al-Karîm alRaḥmân fî Tafsîr Kalâm al-Mannân, ed. 'Abd al-Raḥmân ibn Ma'lâ alLuyahiq. Beirut: Mu'assasah al-Risâlah.

al-Samarqandî, Abû al-Layth Naṣr ibn Muhamammad ibn Aḥmad ibn Ibrâhîm. n.d. Tafsîr Bahrr al-'Ulûm. Beirut: Dâr al-Kutub al'Ilmiyah.

al-Suyûtîn, 'Abd al-Raḥmân Jalâl al-Dîn ibn Abî Bakr. n.d. al-Dur al-Manthûr. Beirut: Dâr al-Fikr.

al-Ṭabarî, Abû Ja'far Muhammad ibn Jarîr ibn Yazîd ibn Kathîr ibn Ghâlib al-Amalî. 2000. Jami' al-Bayân fì Ta'wûl al-Qur'ân, ed. Ahmad Muhammad Shâkir. Beirut : Mu'assasah al-Risâlah.

al-Zamakhsharî, Abû al-Qâsim Maḥmûd ibn 'Amr ibn Aḥmâd. 1407 H. alKashshâf 'an Haqâiiq Ghawâmiḍ al-Tanzîl. Beirut: Dâr Kitâb al-'Arabî.

al-Zuhạylî, Wahbah ibn Musțafâ. 1418 H. al-Tafsîr al-Munîr fî al-Aqîdah wa al-Sharî́ah wa al-Manhajah. Damascus: Dâr al-Fikr al-Mu'âṣir. 